\title{
Influence of tooth location on coronally advanced flap procedures for root coverage
}

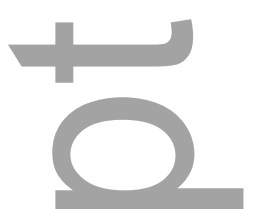

Giovanni Zucchelli $\ddagger$, DDS, PhD, Lorenzo Tavelli†‡, DDS, Andrea Ravidà†, DDS, MS, Stefanini Martina ${ }^{*}$, DDS, MS, Fernando Suárez-López del Amo§, DDS, MS, Hom-Lay Wang†, DDS, MS, PhD

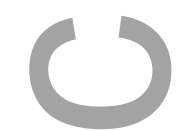

* Department of Biomedical and Neuromotor Sciences, University of Bologna, Bologna, Italy

† Department of Periodontics \& Oral Medicine, University of Michigan School of Dentistry, Ann Arbor, MI, USA

$\S$ Department of Periodontics, University of Oklahoma Health Sciences Center, Oklahoma City, OK, USA

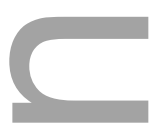

‡Contributed equally to this study

Corresponding author:

Hom-Lay Wang, DDS, MSD, PhD

Department of Periodontics and Oral Medicine, University of Michigan School of Dentistry

1011 North University Avenue

Ann Arbor, Michigan 48109-1078, USA.

E-mail address: homlay@umich.edu

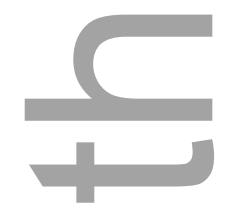

Word count: 4,033

Tables and figures: 4 tables, 2 figures

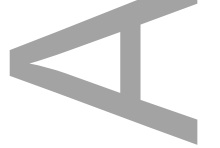

This is the author manuscript accepted for publication and has undergone full peer review but has not been through the copyediting, typesetting, pagination and proofreading process, which may lead to differences between this version and the Version of Record. Please cite this article as doi:

10.1002/JPER.18-0201.

This article is protected by copyright. All rights reserved. 
Running title: Influence of tooth location on CAF root coverage

References: 82

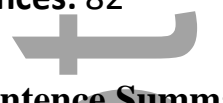

One sentence Summary: Tooth location plays an important role when coronally advanced flap procedures are performed for the treatment of localizes gingival recessions

Key words: gingival recession, tooth, surgical flaps, evidence-based dentistry

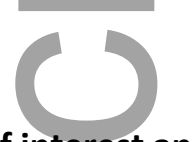

Conflict of interest and source of funding: The authors do not have any financial interests, either directly or indirectly, in the products or information listed in the paper. This paper was partially supported by the University of Michigan Periodontal Graduate Student Research Fund.

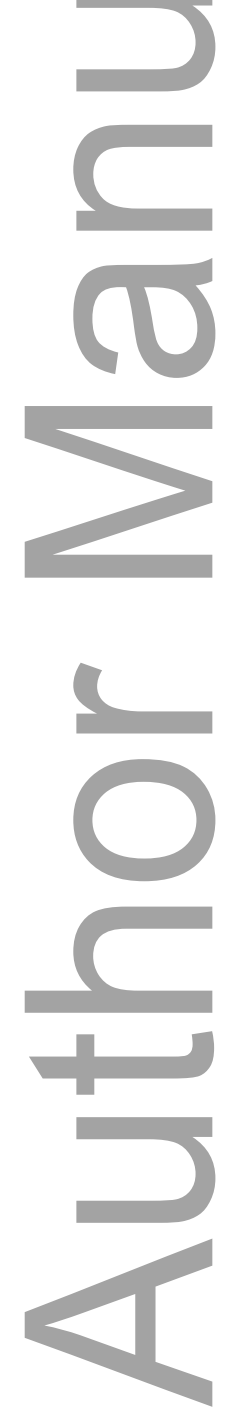

This article is protected by copyright. All rights reserved. 


\section{Abstract}

Background: The efficacy of Coronally Advance Flap (CAF) has been extensively evaluated and several parameters influencing the final results, such as interproximal attachment loss, recession defect size, papilla dimension, flap thickness, have also been identified. However, the influence of tooth location has not been systematically investigated yet. Therefore, the aim of this systematic review was to evaluate the influence of tooth location on the outcomes of CAF.

Material and Methods: A literature search on PubMed, EMBASE, Cochrane libraries and handsearched journal until September 2017 was performed to identify clinical studies reporting the outcome of CAF for localized gingival recessions (GRs) for each single tooth.

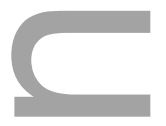

Results: Eighteen articles reporting 399 localized GRs treated with CAF were included in the present systematic review. Canines and incisors were related to a higher $\mathrm{mRC}$ and $\mathrm{CRC}$ than premolars and molars (odds ratio 1.63) $(p<0.05)$, while the right side showed a higher CRC than the left side (odds ratio 1.60$)(p<0.05)$. No differences were found between maxillary and mandibular dentition ( $p>0.05)$. The addition of a graft such as Connective Tissue Graft (CTG) with or without Enamel Matrix Derivative (EMD) was shown to enhance the outcomes compared to CAF alone $(p<0.05)$. CRC was negatively affected by initial clinical attachment level $(p<0.05)$, but not from the initial recession depth $(p>0.05)$.

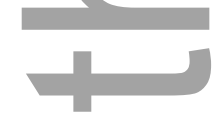

Conclusions: Tooth location plays an important role on $\mathrm{mRC}$ and $\mathrm{CRC}$ following CAF. The addition of CTG or substitutes, especially with biological agents (EMD), enhance the clinical outcomes compared to $\mathrm{CAF}$ alone.

This article is protected by copyright. All rights reserved. 


\section{Introduction}

Gingival recession $(G R)$ is defined as the apical shift of the gingival margin with the concomitant exposure of a portion of the root surface ${ }^{1}$. This condition affects a large part of population, regardless of the standard of oral hygiene ${ }^{2,3}$. It is estimated that $54.5 \%$ of young adults and $100 \%$ of middle-elderly adults suffer from GRs, with an average prevalence of $78.6 \%{ }^{2}$. More recently, Rios et al. reported a prevalence of $99.7 \%$ of $\mathrm{GRs} \geq 1 \mathrm{~mm}$ among Brazilian population, and that gender, age, smoking and high education were risk factors for buccal GR ${ }^{4}$. Nieri and coworkers showed that $80 \%$ of patients had one or more buccal GRs and that their perception of GRs was greater on anterior areas, deep GRs and among young patients ${ }^{5}$. The high prevalence of these mucogingival defects can be attributed to a large variety of predisposing and precipitating factors that include but are not limited to: plaque-induced inflammation ${ }^{1}$; toothbrush trauma ${ }^{6}$; periodontal disease $^{7}$, malposition ${ }^{2}$; frenum pull; iatrogenic; improper flossing ${ }^{8}$; trauma associated with class II malocclusion ${ }^{9}$; piercing trauma $^{10}$; and orthodontic treatment ${ }^{11}$.

When GR affects the esthetic area and/or it is associated with dental hypersensitivity, exhibits a lack of an adequate band of keratinized tissue, or is concomitant with a carious or noncarious cervical lesion, treatment is often indicated ${ }^{1,12}$. Indeed, the efficacy of surgical treatment for correction of GR defects has been extensively demonstrated ${ }^{13}$ with long-term stable outcomes ${ }^{14}$.

Several surgical techniques, such as guided tissue regeneration $(\mathrm{GTR})^{15}$; subepithelial connective tissue graft procedure $(\mathrm{SCTG})^{16}$; coronally advanced flap $(\mathrm{CAF})^{17}$; lateral positioned flap ${ }^{18}$; double papilla technique ${ }^{19}$; semilunar pedicle $\mathrm{flap}^{20}$; oblique rotated flap ${ }^{21}$; tunnel technique ${ }^{22}$; and surgical techniques based on modifications of these protocols ${ }^{23}$, have been proposed for the treatment of GR defects. Among these procedures, it has been demonstrated that CAF represents 
the most predictable technique for the correction of GR defects ${ }^{13,24}$. Similarly, although several connective tissue substitutes have been tested in attempt to eliminate the drawbacks related with a secondary surgical site ${ }^{25-28}$, however, autogenous connective tissue graft (CTG) remains to be considered the gold standard providing with the most predictable and long-term satisfactory results $1,13,29$.

The final outcomes of the CAF procedures depend not only on the origin of the graft but also on several critical anatomical factors ${ }^{30}$. Indeed, several investigations have highlighted the impact of not only Miller's classification, but also the recession defect size; interdental papilla dimension; root prominence; quantity of keratinized tissue; tooth location; and the concomitant presence of noncarious cervical lesions ${ }^{31-35}$. Among these, tooth location should be further evaluated since it may play a key role of importance. Although it is believed that optimal results of periodontal plastic surgery may in certain areas be more challenging to obtain ${ }^{30,36-38}$, no studies have investigated yet the outcome of CAF depending on each specific tooth location.

The need for evaluating the predictability of CAF in the different locations in the oral cavity becomes apparent when the results of the different studies are being compared without regard to the specific teeth treated. In addition, several clinical studies have investigated only certain areas limited to maxillary canines and premolars ${ }^{12}$. Indeed, studies that treated recessions localized in both the maxilla and the mandible reported better outcomes for maxillary teeth ${ }^{39-41}$. According to McGuire and Scheyer, vascular supply and muscle pull may negatively influence the outcome of periodontal plastic surgery in the lower jaw ${ }^{38}$. Moreover, anatomic conditions like marginal frenula, high muscle pull and shallow vestibule that are frequently encountered in the lower incisors are considered limiting factors for periodontal plastic surgery ${ }^{1}$. Given the influence of tooth location on the outcomes of periodontal plastic surgery, it is of paramount importance to understand the true 
probability of achieving a complete root coverage following CAF in different anatomical areas. Hence, the aim of this systematic review was to evaluate the clinical outcomes of CAF in relation to the location of the GR defect.

\section{Material and Methods}

Study Registration

The review protocol was registered and allocated the identification number (CRD42017081100) in the PROSPERO International Prospective Register of Systematic Reviews hosted by the National Institute for Health Research, University of York, Centre for Reviews and Dissemination.

\section{Eligibility Criteria}

Articles were included in this systematic review if they met the following criteria: 1) Patients with a clearly specified diagnosis of localized gingival recession, 2) GRs classified as Miller class I or II or RT1 ${ }^{31,42}, 3$ ) Randomized clinical trials, controlled prospective studies, Cohort, case series and retrospective studies involving human participants that reported results in terms of percentage of root coverage per tooth by using CAF technique, 4) Case series with at least 10 recessions. Accordingly, articles were to be excluded if: 1) Case report; 2) Systematic review; 3) Preclinical animal studies; 4) Articles not reporting the results of each specific tooth; 5) Articles not using CAF as surgical technique; 6) Articles using the envelope CAF design; 7) articles using CAF for treating multiple gingival recessions; 8) articles considering only Miller class III and/or IV GRs. For articles reporting both single and 
multiple recessions, or both Miller class I/II and III, only data regarding Miller class I/II localized GRs were included in the present systematic review.

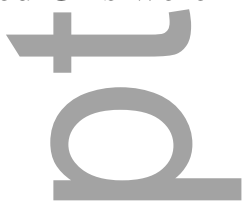

Patient, Intervention, Comparison, Outcome (PICO) Question

This systematic review utilized the Preferred Reporting Items Systematic review and Meta-Analyses (PRISMA) statement and checklist ${ }^{43}$, as well as the patient, intervention, comparison, outcomes (PICO) method

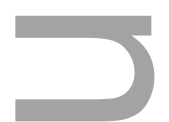

Types of patients

Patient with localized GR defects classified as Miller I, $\|^{31}$ or RT1 (Recession Type 1$)^{42}$. A table reporting the specific teeth treated together with the related outcomes following CAF must be provided in order to include the article in the present review.

Types of interventions

All the recessions treated with conventional $\mathrm{CAF}^{44,45}$ has been considered. Only flaps with two vertical releasing incisions, de-epithelialization of the surgical papillae and a suturing positioned coronally advanced position respect to the CEJ have been included.

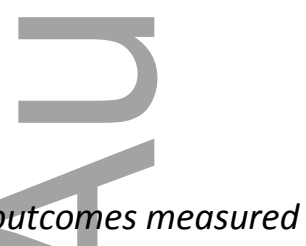

Types of outcomes measured

This article is protected by copyright. All rights reserved. 
The primary outcome was to investigate the mean root coverage $(\mathrm{mRC})$ and the complete root coverage (CRC) of CAF for each single tooth. The secondary outcomes were: (a) to compare the mRC and the CRC in the upper and lower jaw, (b) to evaluate the influence of autologous CTG or substitutes, c) to evaluate the influence of CTG or substitutes on keratinized tissue (KT) gain, (d) to assess the buccal probing depth reduction and the clinical attachment level (CAL) gain for each single tooth and e) to evaluate which factors affect the $\mathrm{MRC}, \mathrm{CRC}, \mathrm{KT}$ gain and CAL gain.

Types of studies

Randomized clinical studies (RCTs), controlled clinical trials, prospective cohort studies, case series were considered in this systematic review.

Only RCTs were considered when logistic regression model was performed.

\section{Focused question}

In patients presenting localized gingival recessions, what is the influence of tooth location on the outcomes of coronally advanced flap procedures?

\section{Information Sources and Screening Process}

Electronic and manual literature searches, conducted by two independent reviewers (LT and AR), covered studies until November 2017 across the National Library of Medicine (MEDLINE by Pubmed), EMBASE, and the Cochrane Oral Health Group Trials Register 
(see supplementary Data S1 and S2 in online Journal of Periodontology). Additionally, a manual search of related journals, including a complete search of Journal of Clinical Periodontology, Journal of Periodontal Research, Journal of Periodontology, Journal of Dental Research, International Journal of Periodontics and Restorative Dentistry, was also performed. Finally, previous systematic reviews investigating root coverage procedures for gingival recession were screened for article identification (see supplementary Data S3 in online Journal of Periodontology). Several authors were contacted to obtain specific data for each tooth treated.

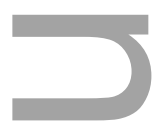

\section{Data extraction}

Studies were excluded by two authors through screening of titles and abstracts (LT and AR). The definitive stage of screening involved full-text reading by the same two reviewers using a predetermined data extraction form to confirm the eligibility of each study based on the aforementioned inclusion and exclusion criteria. The primary outcomes were the $\mathrm{mRC}$ and CRC, while the secondary outcomes were KT gain and CAL gain. Data was then independently extracted by these two review authors. Patient characteristics, treatments and clinical outcomes were systematically registered. When clinical data was lacking, authors of the trials were contacted.

Where clinical data were provided at multiple time points, the follow-up closest to 1 year was used.

At each stage, disagreement between reviewers was resolved through discussion and consensus. If a disagreement persisted, the judgment of a third reviewer (F.S.) was decisive. 


\section{Statistical analysis}

All statistical analyses were performed using the Rstudio software environment $\|$.

To compare the outcomes of RCTs and non-RCTs, independent sample t-tests and in case of paired data, a paired sample t-test was performed where a $\mathrm{p}<0.05$ was deemed significant.

Logistic regression analyses were performed based on data from RCTs. For continuous data logistic regression models were created to assess the roles and influence of several variables to predictor outcome variables. For binary outcomes logistic regression models were created to similarly assess the influence of the different parameters on the outcome. Additionally, scatter plots and box plots were produced to better visualize the pattern of influence of specific factors on the outcomes.

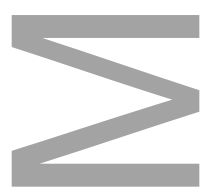

\section{Quality and Risk of Bias assessment}

The Cochrane Risk of Bias Tool for RCTs has been used to evaluate the studies ${ }^{46}$. The assessment of the quality of nonrandomized studies and case series has been evaluated using the NewcastleOttawa scale ${ }^{47}$ and the Johanna Briggs Institute Scale for Case Series ${ }^{48}$, respectively (see supplementary Data S4 in online Journal of Periodontology).

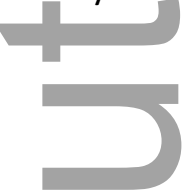

Results

\section{Study selection}

This article is protected by copyright. All rights reserved. 
The search results based on PRISMA guidelines are depicted in supplementary Data S1 in the online Journal of Periodontology. The electronic search in MEDLINE, through Pubmed, identified 2179 articles until September 2017, while the EMBASE and Cochrane Library searching provided 219 and 114 records, respectively. Thirteen articles were identified through manual searching. After eliminating duplicates, 2232 articles were selected. Among these, 191 articles met the inclusion criteria when their titles and abstracts were examined and therefore were considered eligible for the full text assessment of eligibility. After reading the full-text, 170 articles were excluded due to insufficient data on specific locations, while 7 studies were excluded because they treated only multiple GRs, only class RT2 GRs or flap design different from CAF (supplementary Data S5 in online Journal of Periodontology). The $\mathrm{k}$ value for inter-reviewer agreement for potentially relevant articles was 0.85 (titles and abstracts) and 0.89 (full-text articles), indicating a consistent agreement between the two reviewers. The supplementary data of 4 articles were provided by 4 authors after being contacted ${ }^{49-52}$. Hence, 18 articles reporting 399 localized GRs treated with CAF, with a mean follow-up of 9.6 months, were included in the present systematic review (Table 1).

\section{Study characteristics}

Study design and study population

Twelve articles were RCTs ${ }^{25,}{ }^{49-59}, 2$ case-control ${ }^{60,61}$ and 4 were case series ${ }^{62-65}$. The general characteristics of the included articles are depicted in Table 1.

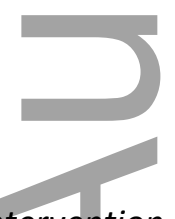

Type of Intervention

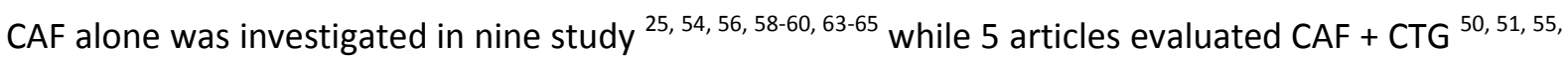
This article is protected by copyright. All rights reserved. 
${ }^{60,61}, 2 \mathrm{CAF}+$ Xenogeneic Collagen Matrix $(\mathrm{XCM})^{49,61}, 1 \mathrm{CAF}+$ Acellular Dermal Matrix (ADM) ${ }^{57}, 4$ $\mathrm{CAF}+$ Enamel Matrix Derivative (EMD) ${ }^{52-54,56}, 1 \mathrm{CAF}+$ Free Rotated Papilla Autograft (FRPA) ${ }^{62}, 1 \mathrm{CAF}$ + Platelet-Rich Plasma (PRP) ${ }^{25}$, and 1 CAF + Periosteal Pedicle Graft (PPG) ${ }^{55}$. The general characteristics of the intervention and results are depicted in Table 2.

\section{Bias assessment}

The results of bias risk assessment for the included RCTs, using The Cochrane Risk of Bias Tool, are summarized in supplementary Data S6 in the online Journal of Periodontology; 6 articles were considered to have a low risk of bias ${ }^{25,50,51,54-56}, 4$ studies were considered to have a moderate risk of bias $52,53,57,58$, and 2 studies a high risk of bias ${ }^{49,59}$.

The results of bias risk assessment for the included case-control using the Newcastle-Ottawa scale, are summarized in supplementary Data S7 in the online Journal of Periodontology; The scores obtained were 760 and $6^{61}$, showing an acceptable (low-medium risk of bias) methodologic level of evidence. The results of bias risk assessment for the included case series, using The Joanna Briggs Institute Scale for Case Series, are summarized in supplementary Data S8 in online Journal of Periodontology; low risk of bias was determined for 2 studies ${ }^{64,65}$, while the remaining 2 were considered to have a moderate risk of bias ${ }^{62,63}$.

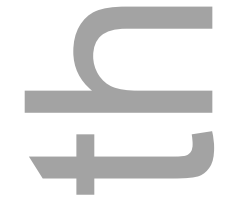

\section{Synthesis of results}

To quantitatively address the review questions, data from all the selected studies was extracted and organized into tables to condense an overview of the included investigations, characteristics of the 
interventions and reported clinical outcome parameters (mRC, CRC, KT gain). $\mathrm{mRC}, \mathrm{CRC}, \mathrm{KT}$ gain, PD red and CAL gain were calculated where not already specified by the authors.

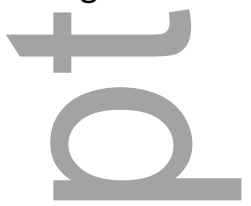

A total of 399 GRs from 18 studies were evaluated in the present systematic review. Among them, 269 GRs were provided by RCTs. Independent sample t-test comparing mRC and CRC for each site showed that there is no difference between the outcomes reported by RCTs and non-RCTs ( $p>0.05$ ). The average $\mathrm{mRC}$ and $\mathrm{CRC}$ for each tooth location was heterogeneous (Fig. 1). Maxillary canines were the most treated teeth $(34.3 \%)$, while maxillary first premolars and mandibular central incisors were the second and the third most selected teeth for root coverage (19.0 and $10.8 \%$ respectively). On the other hand, right maxillary lateral incisor and right mandibular second premolar were the least treated teeth and no information was available for second molars. Table 3 depicts the frequency with which each tooth has been included in the selected studies.

\section{Regression analysis}

Logistic regression model was performed only considering data from RCTs. No significant differences were observed when the effect of different operators on the outcomes of $\mathrm{MRC}, \mathrm{CRC}, \mathrm{KT}$ gain, PD red, CAL gain were explored for each tooth site $(p>0.05)$. Anterior teeth (incisors and canines) were related to significant higher mRC $(p<0.05), C R C(p<0.01)$, KT gain $(p<0.05)$, PD red $(p<0.01)$ and CAL gain $(p<0.01)$ than posterior teeth (premolars and first molars) (Fig. 2A). The odds for achieving CRC for anterior teeth was 1.63 compared to posterior teeth. Maxillary and mandibular teeth showed similar mRC and CRC ( $p>0.05$ ), while KT gain, PD red and CAL gain were found significantly superior in the lower arch $(p<0.001)$ (Fig. $2 B, 2 C)$ Teeth present on the right arches were associated with 
significantly higher CRC than teeth on left arches $(p<0.05)$. The odds of obtaining CRC for right side was 1.6 compared to left side. Although smoking patients showed lower mRC and CRC than nonsmoking patients, this difference was not statistically significant ( $p>0.05$ ) (Fig. 2D).

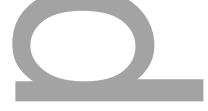

When comparing different grafting material, the addition of CTG, CTG + EMD, or ADM showed superior $\mathrm{mRC}$ and CRC than CAF alone $(\mathrm{p}<0.05)$. Similarly, CAF + CTG showed comparable results, in terms of $m R C$ and $C R C$ with $C A F+A D M, C A F+C T G+E M D, C A F+E M D, C A F+P P G$ and $C A F+P R P$ $(p>0.05)$, while lower results were achieved in CAF $+X C M$ and CAF alone $(p<0.05)$. Significant superior KT gain than CAF alone was found for CAF + CTG + EMD ( $p<0.01), C A F+C T G(p<0.05), C A F+$ ADM $(p<0.05)$ and CAF + PPG $(p<0.05) . C A F+C T G$ was associated with higher KT gain than CTG substitutes $(p<0.05)$. Indeed, KT gain was positively influenced by the initial KT width $(p<0.001)$ and by CAF + CTG $(p<0.001)$. CRC was positively related to initial CAL $(p<0.05)$ but not associated with initial recession depth ( $p>0.05)$; $m R C$ was not affected by initial recession depth and initial CAL $(p>0.05)$. CAL gain was significant affected by initial CAL $(p<0.001)$, while PD red was positively influenced by initial PD $(p<0.001)$ and the use of CAF + CTG $(p<0.01)$ or CAF + EMD $((p<0.001)$. Table 4 compares $\mathrm{MRC}, \mathrm{CRC}, \mathrm{KT}$ gain, PD red and CAL gain based on tooth location.

\section{Discussion}

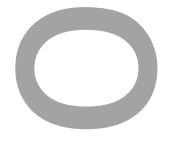

CAF may represent the most investigated flap approach for GR coverage ${ }^{66}$. As such, multiple parameters that can influence the results of this procedure have been investigated including interproximal attachment loss, amount of keratinized tissue, recession defect depth, height of 
papilla, etc. ${ }^{30,67}$. However, among them, the influence of tooth location on the outcome of CAF has not been extensively investigated yet.

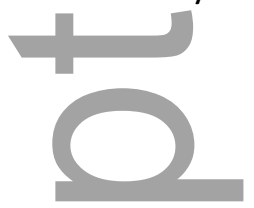

A review addressing the most critical elements for root coverage by De Sanctis and Clementini mentioned the location as a factor that may affect the success, primarily based on $\mathrm{mRC}$ and CRC, of the surgical procedure ${ }^{30}$. Our results confirmed that tooth location is an important parameter that can affect the outcome of CAF, in particular when anterior and posterior teeth were compared. Result from our regression analysis showed a higher $\mathrm{mRC}$ and $\mathrm{CRC}$ in the anterior teeth than in the posterior teeth, with an odds ratio of 1.6 for achieving CRC in canines and incisors compared to premolars and molars. In agreement with our findings, Aroca et al. found that posterior teeth were related to lower outcomes ${ }^{68}$. In this sense, it has been suggested that the amount of KT apically and laterally to the GR may have an impact on $\mathrm{CRC}^{30}$; thus, it can be assumed that the reduced width of attached gingiva that usually characterizes premolars compared to anterior teeth ${ }^{69}$ may have contributed to the lower $\mathrm{mRC}$ and $\mathrm{CRC}$ of the posterior teeth. Therefore it should be considered that it is not tooth location per se but several other factors in combination, such as the amount of KT or the gingival thickness, that are likely to be higher in certain areas of the mouth and thus affecting the outcomes of CAF procedures.

Huang et al. concluded that achieving CRC in maxillary teeth is more predictable than in mandibular teeth, although this trend was not statistically significant ${ }^{36}$. However, our results failed to identify a significant difference in terms of $\mathrm{MRC}$ and $\mathrm{CRC}$ when comparing upper and lower arch. This may be due to the limited sample size and the heterogeneity of the teeth included (19 maxillary vs. 4 mandibular teeth, mostly of them canines) in the study of Huang et al. ${ }^{36}$. On the other hand, logistic regression analysis showed greater KT gain, PD red and CAL gain in the mandible compared to the 
maxilla. Nevertheless, these results should be interpreted cautiously given the non-uniform distribution of the treated teeth between upper and lower jaw, together with the different grafts used.

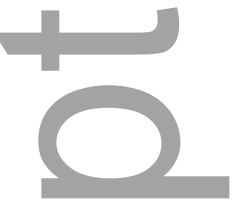

口

Interestingly, teeth in the right side were related to greater CRC than corresponding ones in the left side (odds ratio 1.60). This fact could be explained by the role of tooth brushing technique in the maintenance of the gingival margin over time ${ }^{30,70}$. It could also be speculated that for most of the right-handed patients, the left side is often more traumatized ${ }^{71}$ due to the application of higher pressure during brushing and thus potentially jeopardizing the outcome of the surgery, both in short and long-term.

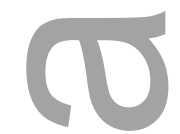

The present review included 399 teeth, mainly maxillary teeth, being more than one third (34.34\%) maxillary canines, followed by maxillary first premolar (19.04\%). As highlighted by Chevalier et al. 2017, most of the studies available in the literature report on anterior maxillary teeth only ${ }^{61}$. Therefore, it can be speculated that the available information for $\mathrm{mRC}$ and CRC of CAF reflects to a greater extent the expected results on the maxillary teeth, especially canines and first premolars. In a meta-analysis evaluating complete root coverage following different procedures, Clauser et al. observed that non-RCTs were related to higher CRC than RCTs. However, our results based only on CAF for single GRs showed that RCT and non-RCTs achieved comparable results.

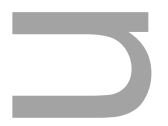

Coronally advanced flap alone is often performed together with CTG or other graft substitutes in an attempt to not only increase root coverage but also increase tissue thickness, augment KT width and 
enhance the esthetic outcomes ${ }^{72}$. Because of the nature of the technique, with or without graft, CAF alone is generally considered a different procedure from CAF + CTG or CAF + CTG substitutes. As it has been clearly demonstrated in the literature, higher clinical outcomes can be obtained whenever a graft is combined with $\mathrm{CAF}^{13,28,73}$. Overall, the addition of a grafting material to CAF (ADM, CTG, CTG + EMD) enhanced the $\mathrm{mRC}, \mathrm{CRC}$ and $\mathrm{KT}$ compared to CAF alone. Despite numerous beneficial effects of CTG when compared to different soft tissue grafting substitutes ${ }^{12,13}$, the main advantage of a graft beneath the flap may be the "scaffold effect" that promotes wound healing with favorable thickening of the gingiva ${ }^{73,74}$. It has been showed that increased marginal soft tissue thickness, which is typically observed when a graft is positioned below the flap, is positively related to higher $\mathrm{mRC}^{74}$ and to a tendency of the gingival margin to coronally migrate over time ${ }^{14,75,76}$. In agreement with Cairo et al., the present study confirm the efficacy of CAF, especially when a CTG with or without EMD is added ${ }^{13,24}$. However, care should be taken when interpreting the results due to the small number of patients in certain included groups (such as CTG + EMD) and the lack of information regarding the patient phenotype or gingiva thickness at the baseline. Indeed, it has been demonstrated that the gingival thickness not only dictate the need of a CTG or a CTG substitute ${ }^{72}$ but it is also one of the main decisive factors that affect the accomplishment of complete root coverage $^{36,77}$.

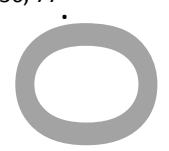

Logistic regression model showed that initial clinical attachment loss is negatively related to CRC, while the initial recession depth does not affect CRC. The importance of clinical attachment loss has always been considered a key factor for final root coverage ${ }^{30}$, as it is the basis of the two main GR classifications ${ }^{31,42}$. On the other hand, whether the baseline depth of the GR affects CRC is controversial in the literature. Several authors reported better results in presence of shallow GRs ${ }^{78,}$ 
${ }^{79}$, while others found higher CRC when the initial GR was deeper ${ }^{80,81}$. However, our results showed that initial recession does not have an effect on CRC.

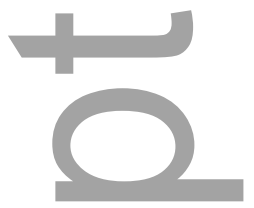

Although the limited sample probably prevented a statistically significant difference, smoking habit seemed to be associated with lower $\mathrm{mRC}$ and CRC. The detrimental effect of tobacco in root coverage procedures in patients smoking more than 10 cigarettes per day has been demonstrated ${ }^{82}$. Therefore, it can be assumed that is the frequency of smoking rather than the habit per se that can cause detrimental results of root coverage procedures. However, out of the 7 articles that included smokers, only 4 reported the cut-off value of 10 cigarettes per day for consider a patient "smoker", while other articles did not report a clear cut-off definition of smoking.

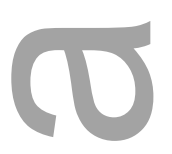

Within the limitations of the present study, several factors can be described. Firstly, the larger part of the studies in the literature did not report the outcome of root coverage procedure for each specific tooth location; secondly, the major part of data was obtained from maxillary teeth, especially canines and first premolars, and thus the $\mathrm{mRC}$ and $\mathrm{CRC}$ of teeth with small sample may not be as representative and generalizable due to possible selection bias. Third, the included studies mainly used CAF alone or CAF + CTG. Moreover, a clear definition of smoking was lacking in some studies. In addition, the heterogeneity of the studies should also be taken into consideration, given the different follow-up, study design, setting and teeth treated. Finally, important parameters that can affect the CRC and $\mathrm{mRC}$ of CAF, such as the gingival biotype/phenotype and the gingival thickness, could not be evaluated.

This article is protected by copyright. All rights reserved. 


\section{Conclusions}

Taking into consideration the limitations of the present study, it can be concluded that tooth location plays an important role on mean root coverage and complete root coverage following coronally advanced flap procedure. Higher outcomes are expected in anterior and right sides compared to posterior and left sides. Clinical attachment loss negatively affects complete root coverage. The addition of connective tissue grafts or substitutes, especially with biological agents, can enhance the clinical outcomes when compared to coronally advanced flap alone.

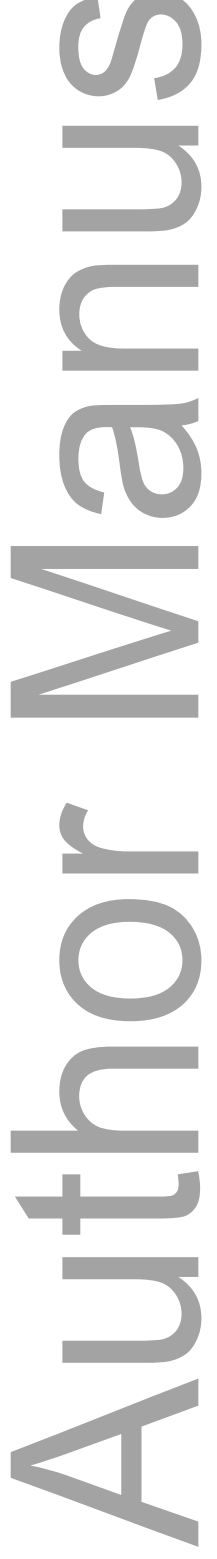

This article is protected by copyright. All rights reserved. 


\section{Indication for further research}

- $\quad$ RCTs based on the CONSORT guidelines

- Increase the number of RCTs that report the $\mathrm{mRC}, \mathrm{CRC}, \mathrm{PD}$ red, KT gain, CAL gain for each specific tooth location

- Further RCT whose results are equally based on maxillary and mandibular recessions, as well as on anterior and posterior teeth

- Studies that include smokers should always report the definition of smokers, specifying also the mean cigarettes/day of the test and control groups

\section{Implications for clinicians}

Clinicians should be aware that CAF, especially when combined to a CTG or substitutes, is a highly effective periodontal plastic procedure for the treatment of single GRs. However, the results presented in the literature mainly describe maxillary canines and premolars and may not be generalizable for other sites. Indeed, the present study revealed that tooth location (whether anterior/posterior or right/left) can affect the outcome of CAF. Clinician should be aware that lower clinical outcomes may be expected when posterior GRs, especially if located in the left side, are treated. In addition, while the initial recession depth seems not related to $\mathrm{mRC}$ or CRC, the initial CAL may limit the CRC.

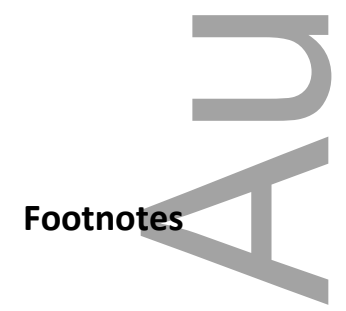

|| Rstudio Version 1.1.383, RStudio, Inc., Massachusetts, USA

This article is protected by copyright. All rights reserved. 


\section{Acknowledgments}

The authors certify that there is no conflict of interest concerning the contents of the study. This paper was partially supported by the University of Michigan Periodontal Graduate Student Research Fund.

The authors would like to thank Dr. Shayan Barootchi (Department of Periodontics and Oral Medicine, University of Michigan, USA) for his assistance in the interpretation of the statistical analyses, Dr. Reino (Department of Surgery, Oral and Maxillofacial Traumatology and Periodontology, School of Dentistry of Ribeirão Preto, USP - Universidade de São Paulo, Ribeirão Preto, SP, Brazil), Dr. Rebele (Private Office Hurzeler/Zuhr, Munich; Department of Operative Dentistry and Periodontology, University School of Dentistry, Albert-Ludwigs-University, Freiburg, Germany) and Dr. Zuhr (Private Office Hurzeler/Zuhr, Munich; Department of Periodontology,

Center for Dental, Oral and Maxillofacial Medicine, Johann Wolfgang Goethe-University, Frankfurt/Main, Germany) for providing additional data for individual GRs treated.

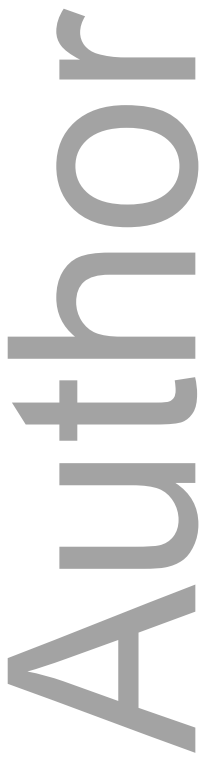

This article is protected by copyright. All rights reserved. 


\section{REFERENCES}

1. Zucchelli G, Mounssif I. Periodontal plastic surgery. Periodontol 2000 2015;68(1):333-68.

2. Gorman WJ. Prevalence and etiology of gingival recession. J Periodontol 1967;38(4):316-22.

3. Serino G, Wennstrom JL, Lindhe J, Eneroth L. The prevalence and distribution of gingival recession in subjects with a high standard of oral hygiene. J Clin Periodontol 1994;21(1):57-63.

4. Rios FS, Costa RS, Moura MS, Jardim JJ, Maltz M, Haas AN. Estimates and multivariable risk assessment of gingival recession in the population of adults from Porto Alegre, Brazil. J Clin Periodontol 2014;41(11):1098-107.

5. Nieri M, Pini Prato GP, Giani M, Magnani N, Pagliaro U, Rotundo R. Patient perceptions of buccal gingival recessions and requests for treatment. J Clin Periodontol 2013;40(7):707-12.

6. Rajapakse PS, McCracken GI, Gwynnett E, Steen ND, Guentsch A, Heasman PA. Does tooth brushing influence the development and progression of non-inflammatory gingival recession? A systematic review. J Clin Periodontol 2007;34(12):1046-61.

7. Loe $\mathrm{H}$, Anerud A, Boysen $\mathrm{H}$. The natural history of periodontal disease in man: prevalence, severity, and extent of gingival recession. J Periodontol 1992;63(6):489-95.

8. Gillette WB, Van House RL. III effects of improper oral hygeine procedure. J Am Dent Assoc 1980;101(3):476-80.

9. Tugnait A, Clerehugh V. Gingival recession-its significance and management. J Dent $2001 ; 29(6): 381-94$.

This article is protected by copyright. All rights reserved. 
10. Er N, Ozkavaf A, Berberoglu A, Yamalik N. An unusual cause of gingival recession: oral piercing. J Periodontol 2000;71(11):1767-9.

11. Joss-Vassalli I, Grebenstein C, Topouzelis N, Sculean A, Katsaros C. Orthodontic therapy and gingival recession: a systematic review. Orthod Craniofac Res 2010;13(3):127-41.

12. Chambrone L, Tatakis DN. Periodontal soft tissue root coverage procedures: a systematic review from the AAP Regeneration Workshop. J Periodontol 2015;86(2 Suppl):S8-51.

13. Cairo F, Nieri M, Pagliaro U. Efficacy of periodontal plastic surgery procedures in the treatment of localized facial gingival recessions. A systematic review. J Clin Periodontol 2014;41 Suppl 15:S44-62.

14. Agudio G, Nieri M, Rotundo R, Franceschi D, Cortellini P, Pini Prato GP. Periodontal conditions of sites treated with gingival-augmentation surgery compared to untreated contralateral homologous sites: a 10- to 27-year long-term study. J Periodontol 2009;80(9):1399-405.

15. Pini Prato G, Tinti C, Vincenzi G, Magnani C, Cortellini P, Clauser C. Guided tissue regeneration versus mucogingival surgery in the treatment of human buccal gingival recession. J Periodontol 1992;63(11):919-28.

16. Langer B, Langer L. Subepithelial connective tissue graft technique for root coverage. J Periodontol 1985;56(12):715-20.

17. Bernimoulin JP, Luscher B, Muhlemann HR. Coronally repositioned periodontal flap. Clinical evaluation after one year. J Clin Periodontol 1975;2(1):1-13.

18. Grupe HE. Modified technique for the sliding flap operation. J Periodontol 1966;37(6):491-5. This article is protected by copyright. All rights reserved. 
19. Harris RJ. The connective tissue and partial thickness double pedicle graft: a predictable method of obtaining root coverage. J Periodontol 1992;63(5):477-86.

20. Tarnow DP. Semilunar coronally repositioned flap. J Clin Periodontol 1986;13(3):182-5.

21. Guinard EA, Caffesse RG. Treatment of localized gingival recessions. Part I. Lateral sliding flap. J Periodontol 1978;49(7):351-6.

22. Zabaleguil, Sicilia A, Cambra J, Gil J, Sanz M. Treatment of multiple adjacent gingival recessions with the tunnel subepithelial connective tissue graft: a clinical report. Int J Periodontics Restorative Dent 1999;19(2):199-206.

23. Zadeh HH. Minimally invasive treatment of maxillary anterior gingival recession defects by vestibular incision subperiosteal tunnel access and platelet-derived growth factor BB. Int J Periodontics Restorative Dent 2011;31(6):653-60.

24. Cairo F, Pagliaro U, Buti J, et al. Root coverage procedures improve patient aesthetics. A systematic review and Bayesian network meta-analysis. J Clin Periodontol 2016;43(11):965-975.

25. Huang LH, Neiva RE, Soehren SE, Giannobile WV, Wang HL. The effect of platelet-rich plasma on the coronally advanced flap root coverage procedure: a pilot human trial. J Periodontol 2005;76(10):1768-77.

26. McGuire MK, Scheyer ET, Nunn M. Evaluation of human recession defects treated with coronally advanced flaps and either enamel matrix derivative or connective tissue: comparison of clinical parameters at 10 years. J Periodontol 2012;83(11):1353-62.

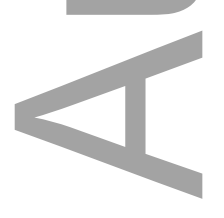

This article is protected by copyright. All rights reserved. 
27. Ozturan S, Oztunc $\mathrm{H}$, Keles Evlice B. Assessment of the soft tissue volumetric changes following acellular dermal matrix grafts with cone beam computerized tomography. Quintessence Int 2015;46(2):171-8.

28. Stefanini M, Jepsen K, de Sanctis M, et al. Patient-reported outcomes and aesthetic evaluation of root coverage procedures: a 12-month follow-up of a randomized controlled clinical trial. J Clin Periodontol 2016;43(12):1132-1141.

29. Chambrone L, Chambrone D, Pustiglioni FE, Chambrone LA, Lima LA. Can subepithelial connective tissue grafts be considered the gold standard procedure in the treatment of Miller Class I and II recession-type defects? J Dent 2008;36(9):659-71.

30. de Sanctis M, Clementini M. Flap approaches in plastic periodontal and implant surgery: critical elements in design and execution. J Clin Periodontol 2014;41 Suppl 15:S108-22.

31. Miller PD, Jr. A classification of marginal tissue recession. International Journal of Periodontics and Restorative Dentistry 1985;5(2):8-13.

32. Saletta D, Pini Prato G, Pagliaro U, Baldi C, Mauri M, Nieri M. Coronally advanced flap procedure: is the interdental papilla a prognostic factor for root coverage? J Periodontol 2001;72(6):760-6.

33. Saletta D, Baldi C, Nieri M, et al. Root curvature: differences among dental morphotypes and modifications after mechanical instrumentation. J Periodontol 2005;76(5):723-30.

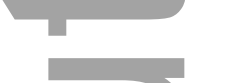

34. Zucchelli G, Testori T, De Sanctis M. Clinical and anatomical factors limiting treatment outcomes of gingival recession: a new method to predetermine the line of root coverage. J Periodontol 2006;77(4):714-21.

This article is protected by copyright. All rights reserved. 
35. Jepsen $\mathrm{K}$, Jepsen $\mathrm{S}$, Zucchelli $\mathrm{G}$, et al. Treatment of gingival recession defects with a coronally advanced flap and a xenogeneic collagen matrix: a multicenter randomized clinical trial. J Clin Periodontol 2013;40(1):82-89.

36. Huang LH, Neiva RE, Wang HL. Factors affecting the outcomes of coronally advanced flap root coverage procedure. J Periodontol 2005;76(10):1729-34.

37. Trombelli L, Schincaglia GP, Scapoli C, Calura G. Healing response of human buccal gingival recessions treated with expanded polytetrafluoroethylene membranes. A retrospective report. J Periodontol 1995;66(1):14-22.

38. McGuire MK, Scheyer ET. Xenogeneic collagen matrix with coronally advanced flap compared to connective tissue with coronally advanced flap for the treatment of dehiscence-type recession defects. J Periodontol 2010;81(8):1108-17.

39. Chambrone LA, Chambrone L. Subepithelial connective tissue grafts in the treatment of multiple recession-type defects. J Periodontol 2006;77(5):909-16.

40. Chambrone LA, Chambrone L. Treatment of Miller Class I and II localized recession defects using laterally positioned flaps: a 24-month study. Am J Dent 2009;22(6):339-44.

41. Hofmanner P, Alessandri R, Laugisch $\mathrm{O}$, et al. Predictability of surgical techniques used for coverage of multiple adjacent gingival recessions--A systematic review. Quintessence Int 2012;43(7):545-54.

42. Cairo F, Nieri M, Cincinelli S, Mervelt J, Pagliaro U. The interproximal clinical attachment level to classify gingival recessions and predict root coverage outcomes: an explorative and reliability study. J Clin Periodontol 2011;38(7):661-6.

This article is protected by copyright. All rights reserved. 
43. Moher D, Liberati A, Tetzlaff J, Altman DG, Group P. Preferred reporting items for systematic reviews and meta-analyses: the PRISMA statement. Journal of Clinical Epidemiology 2009;62(10):1006-12.

44. Allen EP, Miller PD, Jr. Coronal positioning of existing gingiva: short term results in the treatment of shallow marginal tissue recession. J Periodontol 1989;60(6):316-9.

45. de Sanctis M, Zucchelli G. Coronally advanced flap: a modified surgical approach for isolated recession-type defects: three-year results. J Clin Periodontol 2007;34(3):262-8.

46. Higgins JP, Altman DG, Gotzsche PC, et al. The Cochrane Collaboration's tool for assessing risk of bias in randomised trials. BMJ 2011;343:d5928.

47. Stang A. Critical evaluation of the Newcastle-Ottawa scale for the assessment of the quality of nonrandomized studies in meta-analyses. Eur J Epidemiol 2010;25(9):603-5.

48. Moola S, Munn Z, Tufanaru C, et al. Chapter 7: Systematic reviews of etiology and risk. In: Aromataris E, Munn Z (Editors). Joanna Briggs Institute Reviewer's Manual. Adelaide: The Joanna Briggs Institute, 2017

49. Reino DM, Maia LP, Fernandes PG, et al. A Randomized Comparative Study of Two Techniques to Optimize the Root Coverage Using a Porcine Collagen Matrix. Braz Dent J $2015 ; 26(5): 445-50$.

50. Zucchelli G, Marzadori M, Mele M, Stefanini M, Montebugnoli L. Root coverage in molar teeth: a comparative controlled randomized clinical trial. J Clin Periodontol 2012;39(11):1082-8.

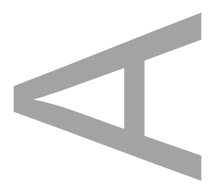

This article is protected by copyright. All rights reserved. 
51. Zucchelli G, Marzadori M, Mounssif I, Mazzotti C, Stefanini M. Coronally advanced flap + connective tissue graft techniques for the treatment of deep gingival recession in the lower incisors. A controlled randomized clinical trial. J Clin Periodontol 2014;41(8):806-13.

52. Zuhr O, Rebele SF, Schneider D, Jung RE, Hurzeler MB. Tunnel technique with connective tissue graft versus coronally advanced flap with enamel matrix derivative for root coverage: a RCT using 3D digital measuring methods. Part I. Clinical and patient-centred outcomes. Journal of clinical periodontology 2014;41(6):582-92.

53. Berlucchi I, Francetti L, Del Fabbro M, Testori T, Weinstein RL. Enamel matrix proteins (Emdogain) in combination with coronally advanced flap or subepithelial connective tissue graft in the treatment of shallow gingival recessions. Int J Periodontics Restorative Dent 2002;22(6):583-93.

54. Del Pizzo M, Zucchelli G, Modica F, Villa R, Debernardi C. Coronally advanced flap with or without enamel matrix derivative for root coverage: a 2-year study. J Clin Periodontol $2005 ; 32(11): 1181-7$.

55. Mahajan A, Bharadwaj A, Mahajan P. Comparison of periosteal pedicle graft and subepithelial connective tissue graft for the treatment of gingival recession defects. Aust Dent J 2012;57(1):51-7.

56. Modica F, Del Pizzo M, Roccuzzo M, Romagnoli R. Coronally advanced flap for the treatment of buccal gingival recessions with and without enamel matrix derivative. A split-mouth study. J Periodontol 2000;71(11):1693-8.

57. Papageorgakopoulos G, Greenwell H, Hill M, Vidal R, Scheetz JP. Root coverage using acellular dermal matrix and comparing a coronally positioned tunnel to a coronally positioned flap approach. J Periodontol 2008;79(6):1022-30.

This article is protected by copyright. All rights reserved. 
58. Pini Prato G, Pagliaro U, Baldi C, et al. Coronally advanced flap procedure for root coverage. Flap with tension versus flap without tension: a randomized controlled clinical study. J Periodontol 2000;71(2):188-201.

59. Pini-Prato G, Baldi C, Pagliaro U, et al. Coronally advanced flap procedure for root coverage. Treatment of root surface: root planning versus polishing. J Periodontol 1999;70(9):1064-76.

60. Bellver-Fernandez R, Martinez-Rodriguez AM, Gioia-Palavecino C, Caffesse RG, Penarrocha M. Surgical treatment of localized gingival recessions using coronally advanced flaps with or without subepithelial connective tissue graft. Med Oral Patol Oral Cir Bucal 2016;21(2):e222-8.

61. Chevalier G, Cherkaoui S, Kruk H, Bensaid X, Danan M. Xenogeneic Collagen Matrix Versus Connective Tissue Graft: Case Series of Various Gingival Recession Treatments. Int J Periodontics Restorative Dent 2017;37(1):117-123.

62. Francetti L, Del Fabbro M, Testori T, Weinstein RL. Periodontal microsurgery: report of 16 cases consecutively treated by the free rotated papilla autograft technique combined with the coronally advanced flap. Int J Periodontics Restorative Dent 2004;24(3):272-9.

63. Harris RJ, Harris AW. The coronally positioned pedicle graft with inlaid margins: a predictable method of obtaining root coverage of shallow defects. Int J Periodontics Restorative Dent $1994 ; 14(3): 228-241$.

64. Huang $\mathrm{LH}$, Wang HL. Sling and tag suturing technique for coronally advanced flap. Int J Periodontics Restorative Dent 2007;27(4):379-85.

65. Pini Prato GP, Baldi C, Nieri M, et al. Coronally advanced flap: the post-surgical position of the gingival margin is an important factor for achieving complete root coverage. J Periodontol $2005 ; 76(5): 713-22$.

This article is protected by copyright. All rights reserved. 
66. Cairo F, Pagliaro U, Nieri M. Treatment of gingival recession with coronally advanced flap procedures: a systematic review. J Clin Periodontol 2008;35(8 Suppl):136-162.

67. Cortellini P, Pini Prato G. Coronally advanced flap and combination therapy for root coverage. Clinical strategies based on scientific evidence and clinical experience. Periodontol 2000 2012;59(1):158-84.

68. Aroca S, Keglevich T, Barbieri B, Gera I, Etienne D. Clinical evaluation of a modified coronally advanced flap alone or in combination with a platelet-rich fibrin membrane for the treatment of adjacent multiple gingival recessions: a 6-month study. J Periodontol 2009;80(2):244-52.

69. Bowers GM. A Study of the Width of Attached Gingiva. J Periodontol 1963;34(3):201-209.

70. Acunzo R, Limiroli E, Pagni G, Dudaite A, Consonni D, Rasperini G. Gingival Margin Stability After Mucogingival Plastic Surgery. The Effect of Manual Versus Powered Toothbrushing: A Randomized Clinical Trial. J Periodontol 2016;87(10):1186-94.

71. Sangnes G. Traumatization of teeth and gingiva related to habitual tooth cleaning procedures. J Clin Periodontol 1976;3(2):94-103.

72. Leong DJ, Wang HL. A decision tree for soft tissue grafting. Int J Periodontics Restorative Dent 2011;31(3):307-313.

73. Graziani F, Gennai S, Roldan S, et al. Efficacy of periodontal plastic procedures in the treatment of multiple gingival recessions. J Clin Periodontol 2014;41 Suppl 15:S63-76.

74. Rebele SF, Zuhr O, Schneider D, Jung RE, Hurzeler MB. Tunnel technique with connective tissue graft versus coronally advanced flap with enamel matrix derivative for root coverage: a RCT

This article is protected by copyright. All rights reserved. 
using 3D digital measuring methods. Part II. Volumetric studies on healing dynamics and gingival dimensions. J Clin Periodontol 2014;41(6):593-603.

75. Pini-Prato GP, Cairo F, Nieri M, Franceschi D, Rotundo R, Cortellini P. Coronally advanced flap versus connective tissue graft in the treatment of multiple gingival recessions: a split-mouth study with a 5-year follow-up. J Clin Periodontol 2010;37(7):644-50.

76. Agudio G, Chambrone L, Pini Prato G. Biologic Remodeling of Periodontal Dimensions of Areas Treated With Gingival Augmentation Procedure: A 25-Year Follow-Up Observation. J Periodontol 2017;88(7):634-642.

77. Baldi C, Pini-Prato G, Pagliaro U, et al. Coronally advanced flap procedure for root coverage. Is flap thickness a relevant predictor to achieve root coverage? A 19-case series. J Periodontol 1999;70(9):1077-84.

78. Clauser C, Nieri M, Franceschi D, Pagliaro U, Pini-Prato G. Evidence-based mucogingival therapy. Part 2: Ordinary and individual patient data meta-analyses of surgical treatment of recession using complete root coverage as the outcome variable. J Periodontol 2003;74(5):741-56.

79. Berlucchi I, Francetti L, Del Fabbro M, Basso M, Weinstein RL. The influence of anatomical features on the outcome of gingival recessions treated with coronally advanced flap and enamel matrix derivative: a 1-year prospective study. J Periodontol 2005;76(6):899-907.

80. Zucchelli G, De Sanctis M. Treatment of multiple recession-type defects in patients with esthetic demands.J Periodontol 2000;71(9):1506-14.

81. Cortellini P, Tonetti M, Baldi C, et al. Does placement of a connective tissue graft improve the outcomes of coronally advanced flap for coverage of single gingival recessions in upper anterior teeth? A multi-centre, randomized, double-blind, clinical trial. J Clin Periodontol 2009;36(1):68-79. 
82. Chambrone L, Chambrone D, Pustiglioni FE, Chambrone LA, Lima LA. The influence of tobacco smoking on the outcomes achieved by root-coverage procedures: a systematic review. J Am Dent Assoc 2009;140(3):294-306.
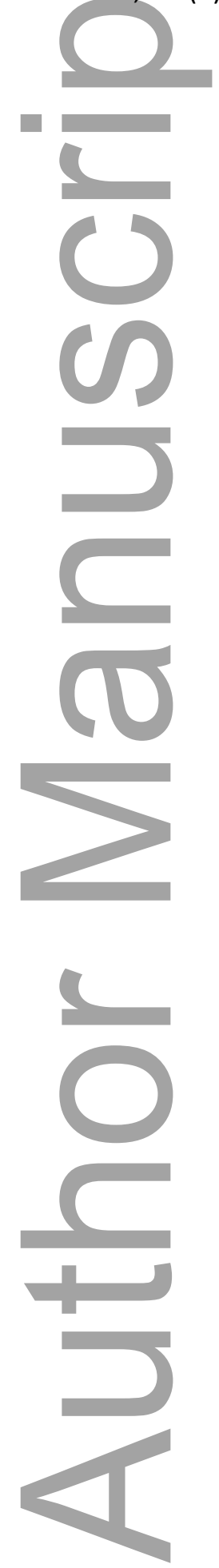

This article is protected by copyright. All rights reserved. 


\section{Figures and Tables}

Figure 1. Mean Root Coverage (mRC) and Complete Root Coverage (CRC) according to the tooth

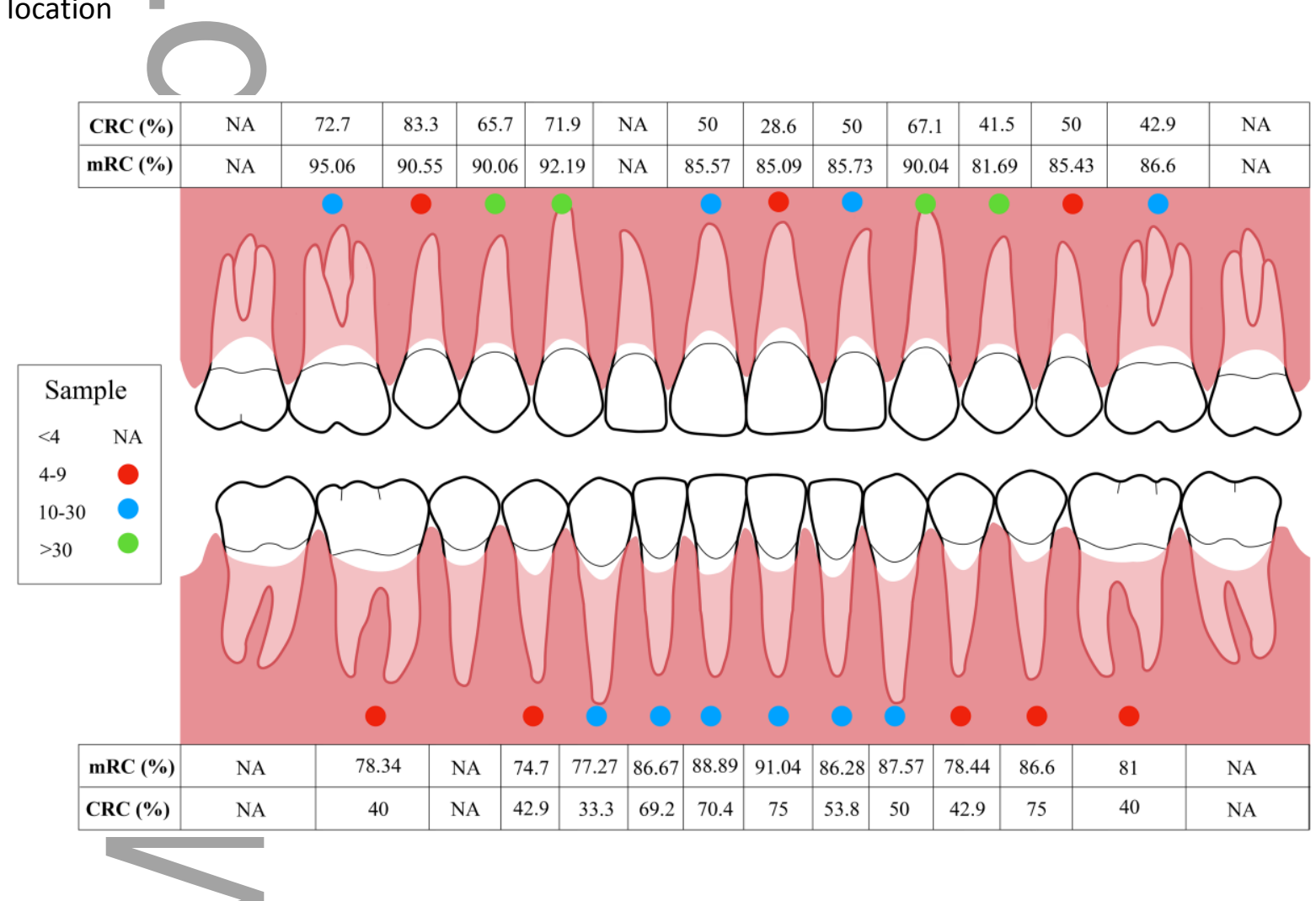

Figure 2. Logistic regression model showing: A) $m R C$ between anterior and posterior teeth, B) KT gain in maxillary and mandibular teeth, C) CAL gain in maxillary and mandibular teeth, D) $\mathrm{mRC}$ in smoking and non-smoking patients.

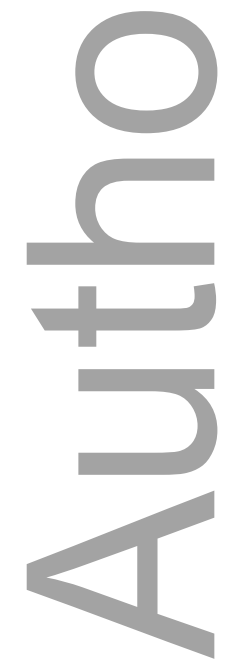

This article is protected by copyright. All rights reserved. 

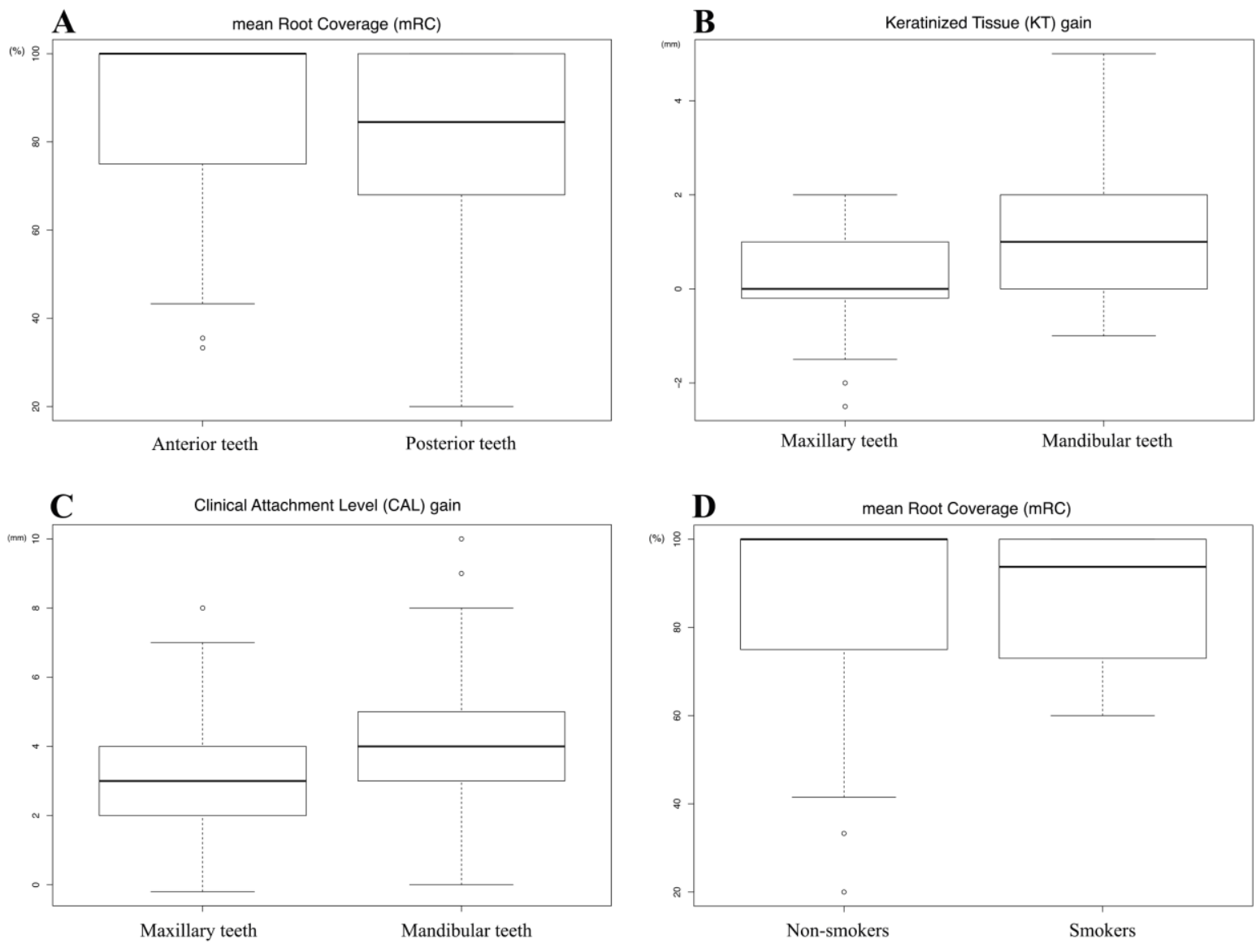

Table 1. Baseline characteristics of the included studies

Table 2. General characteristics of the intervention and results

Table 3. Frequency of treated teeth according to their location

Table 4. Comparison of mean Root Coverage (mRC), Complete Root Coverage (CRC), Keratinized

Tissue Gain (KT gain), Probing Depth reduction (PD red) and Clinical Attachment Level gain (CAL gain) based on tooth location

\section{Supplementary data}

This article is protected by copyright. All rights reserved. 
Data S1. PRISMA flowchart

Data S2. Electronic search strategy

Data S3. References of the previous systematic reviews screened for articles identification

Data S4. Bias assessment scales and related parameters for the evaluation of risk of bias

Data S5. Characteristics and references of the excluded articles

Data S6. The results of the bias risk assessment for the included RCTs using The Cochrane Risk of Bias Tool for Randomized Controlled Trials

Data S7. The results of the bias risk assessment for the included non-randomized trials studies using the Newcastle-Ottawa quality assessment scale

Data S8. The results of the bias risk assessment for the included case series using The Joanna Briggs Institute Scale for Case Series

Table 1. General overview of the included studies

\begin{tabular}{|c|c|c|c|c|c|}
\hline $\begin{array}{l}\text { Study } \\
\text { design, } \\
\text { follow-up }\end{array}$ & $\begin{array}{l}\text { Mean Age } \\
\text { (years), } \\
\text { Patients (N) } \\
\text { and } \\
\text { Recessions } \\
\text { (N) }\end{array}$ & $\begin{array}{c}\text { Smoking } \\
\text { habits }\end{array}$ & $\begin{array}{l}\text { Recession } \\
\text { type }\end{array}$ & Location & $\begin{array}{c}\text { Site, } \\
\text { setting and } \\
\text { funding }\end{array}$ \\
\hline $\begin{array}{l}\text { Bellver-Fernandez et } \\
\text { al. } 2016^{60}\end{array}$ & $\begin{array}{l}\text { Mean age: } \\
39.6 \pm 9.3 \\
\text { Recruited } \\
\text { patients: } 17 \\
\text { Drop-out }\end{array}$ & $\begin{array}{l}4 \text { Patients } \\
\text { were } \\
\text { smokers } \\
\text { (>10 } \\
\text { cig/day) }\end{array}$ & $\begin{array}{l}\text { Miller I, II, } \\
\quad \text { III } \\
\text { Localized } \\
\text { GRs } \\
\text { Rec O NR }\end{array}$ & $\begin{array}{c}\text { Maxillary and } \\
\text { mandibular } \\
\text { teeth }\end{array}$ & $\begin{array}{c}\text { Spain, } \\
\text { Private } \\
\text { practice, NR }\end{array}$ \\
\hline
\end{tabular}

This article is protected by copyright. All rights reserved. 
patient: 0

GRs: 22

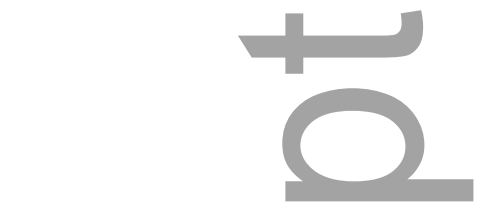

Berlucchi et al. 2002 53
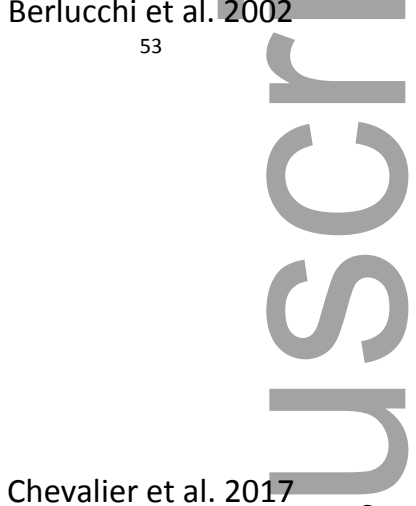
Case-control

Del Pizzo et al. 2005 54 RCT

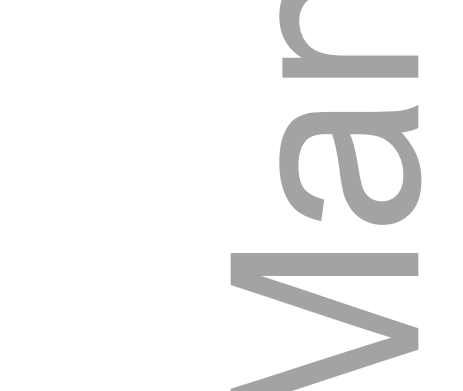

RCT

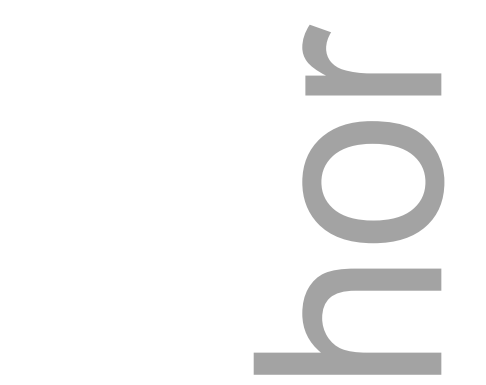

Francetti et al. 2004

62

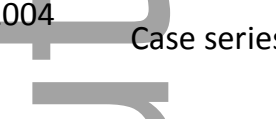

Mean age:

30.6

Recruited

patients: 14

Drop-out

patients: 0

GRs: 26

Mean age:

38.75

Recruited

patients: 4

Drop-out

patients: 0

GRs: 17

Mean age:

$39.46 \pm 10.7$

Recruited
patients: 15

Drop-out

patients: 0

GRs: 30

Mean age:

$30.3 \pm 6.3$

Recruited

patients: 16

NR

Non-

smoking

patients

Non-

smoking

patients

patients

Drop-out

patients: 0
Miller I, II

$$
\begin{aligned}
& \text { Localized } \\
& \text { and } \\
& \text { multiple } \\
& \text { GRs }
\end{aligned}
$$
Maxillary and mandibular teeth

Rec 0 NR

Miller I

Localized and

multiple GRs

Rec 0 NR

Miller I, II

Localized GRs

$\operatorname{Rec} 0 \geq 3$ $\mathrm{mm}$
Maxillary and mandibular teeth
France, University, NR
Maxillary and mandibular canines and first premolars
Italy, University, NR

$\begin{array}{cc}\text { Miller I, II } & \text { Maxillary and } \\ \text { Localized } & \begin{array}{c}\text { mandibular } \\ \text { GRs }\end{array} \\ \text { teeth. Molars } \\ \text { wec } 0 \geq 2.5 & \text { included } \\ \mathrm{mm} & \end{array}$

GRs: 16 


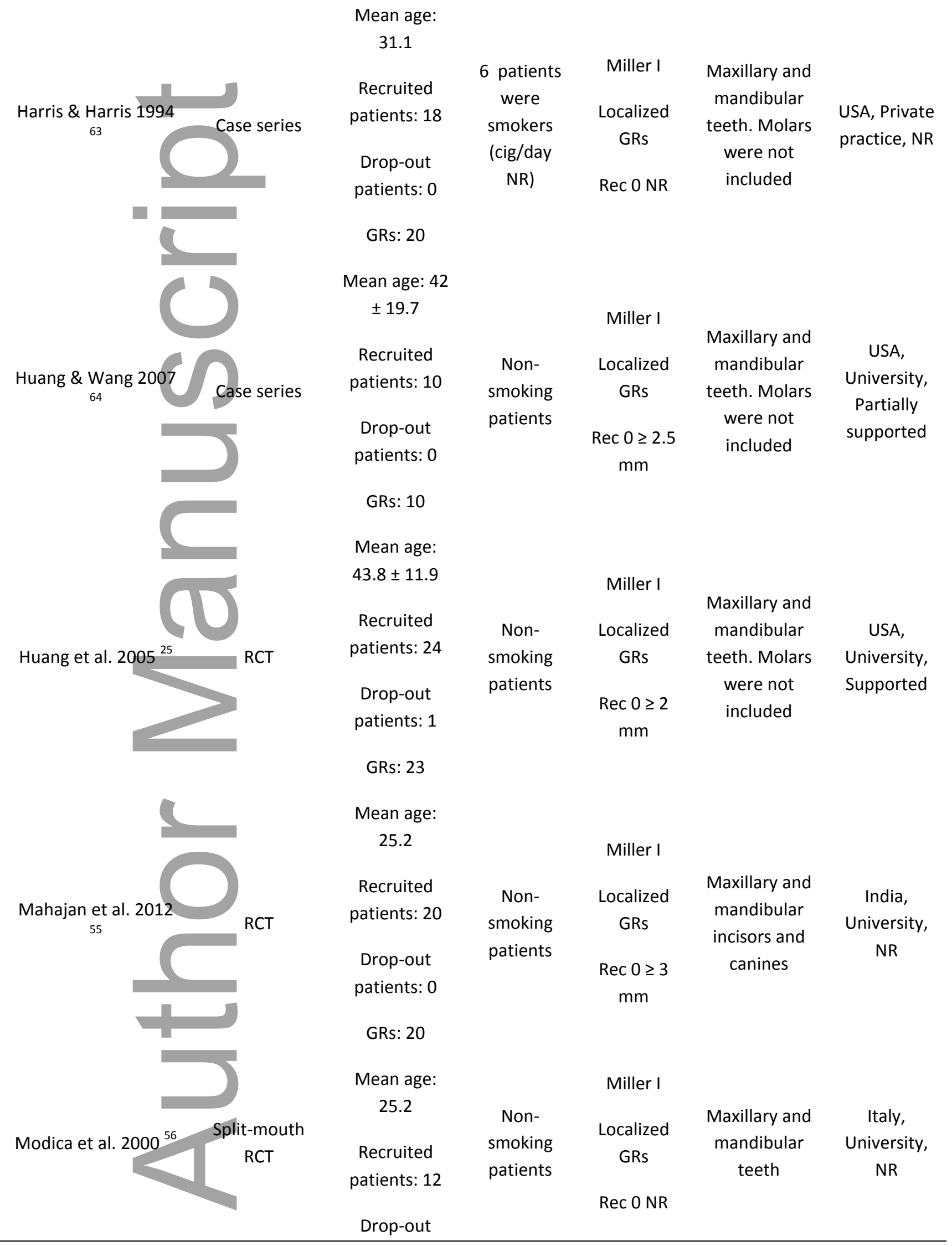

This article is protected by copyright. All rights reserved. 
patients: 0

GRs: 24

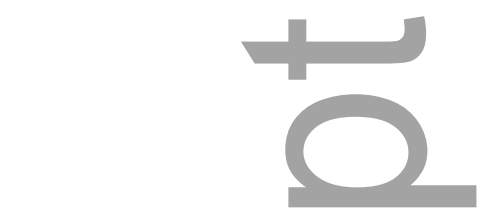

Papageorgakopoulos RCT

et al. $2008^{57}$

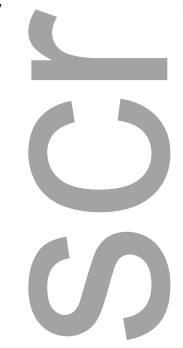

Pini Prato et al. $1999 \quad$ Split-mouth

59

RCT
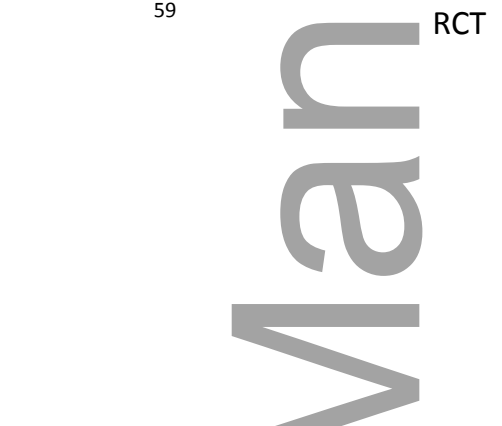

Pini Prato et al. $2000 \quad$ Split-mouth 58

RCT
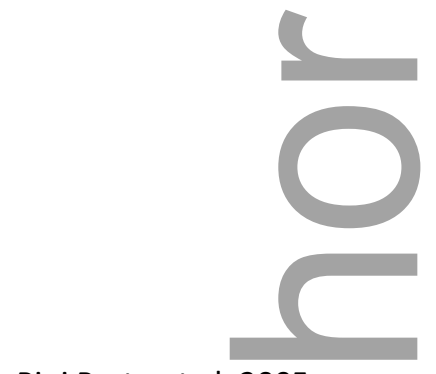

Pini Prato et al. 2005

65 Case-series

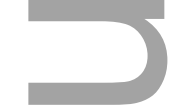

Mean age: 41

$$
\pm 13
$$

Recruited

patients: 24

Drop-out

patients: 2

GRs: 24

Mean age:

$33.6 \pm 9.9$

Recruited

patients: 10

Drop-out

patients: 0

2 Patients

were

smokers

(cig/day

NR)

GRs: 20

Mean age:

$32.3 \pm 6.3$

Recruited

patients: 11

Drop-out

patients: 0

3 patients

were

smokers

(cig/day

NR)

GRs: 22

Mean age:

$29.70 \pm 6.04$

Recruited
patients: 60
Drop-out
patients: 0

11 patients

were smokers (>

$10 \mathrm{cig} /$ day)
Miller I, II

Maxillary and

Localized mandibular

teeth. Molars

were not

$\operatorname{Rec} 0 \geq 3$

$\mathrm{mm}$
USA,

University, Partially supported
Miller I, II

Localized
GRs

$\operatorname{Rec} 0 \geq 2$

$\mathrm{mm}$

$$
\begin{array}{cc}
\text { Maxillary } & \text { Italy, } \\
\text { incisors, } & \text { University, } \\
\text { canines and } & \text { NR } \\
\text { premolars } &
\end{array}
$$

\section{Miller I}

Localized

GRs

$\operatorname{Rec} 0 \geq 2$

$\mathrm{mm}$
Maxillary and mandibular teeth. Molars were not included
Italy, Private practice, NR

GRs: 60

Miller I

Localized

GRs

$\operatorname{Rec} 0 \geq 2$

$\mathrm{mm}$
Maxillary

teeth. Molars Italy, Private were not included 


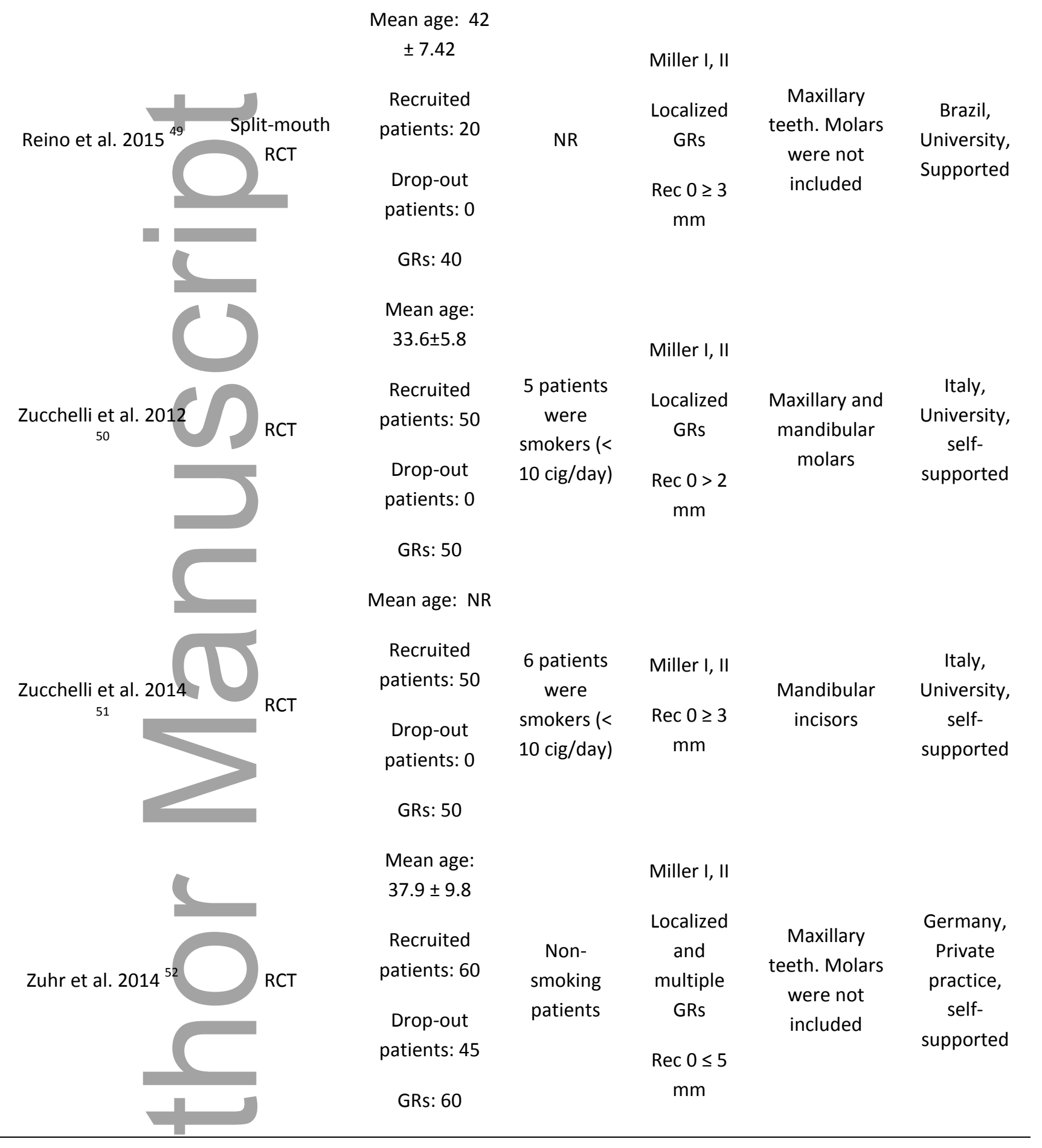

Note. RCT: Randomized Controlled Trial. N: number. GRs: Gingival Recessions. NR: not reported.

$\mathrm{Cig} /$ day: cigarettes a day. Rec 0: baseline recession depth.

This article is protected by copyright. All rights reserved. 

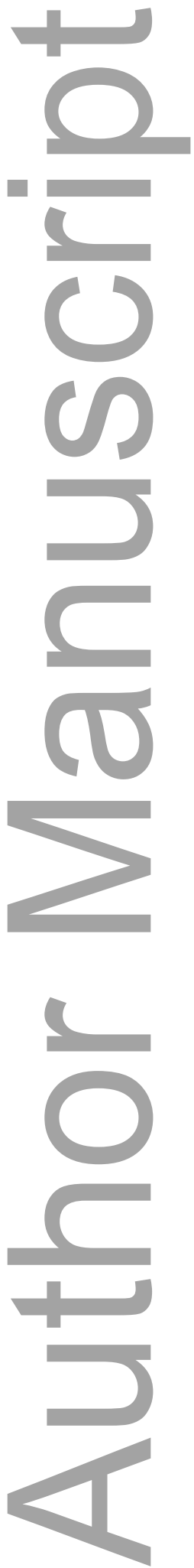

This article is protected by copyright. All rights reserved. 
Table 2. General characteristics of the intervention and results

\begin{tabular}{|c|c|c|c|c|c|c|}
\hline $\begin{array}{c}\text { Preoperativ } \\
\text { y } \\
\text { preparation }\end{array}$ & $\begin{array}{c}\text { Treatmen } \\
\text { t (control } \\
\text { group) }\end{array}$ & $\begin{array}{l}\text { Treatmen } \\
\qquad \mathbf{t} \\
\text { (test } \\
\text { group) }\end{array}$ & $\begin{array}{l}\text { Post- } \\
\text { surgical } \\
\text { treatmen } \\
\quad t\end{array}$ & $\begin{array}{l}\text { Follow- } \\
\text { up } \\
\text { (months } \\
\text { ) }\end{array}$ & $\begin{array}{c}\mathrm{mRC} \pm \\
\mathrm{SD} \\
(\%)\end{array}$ & $\begin{array}{c}\text { Authors } \\
\text { conclusio } \\
\mathbf{n}\end{array}$ \\
\hline $\begin{array}{l}\text { Bellver-Fernandez } \\
\text { et al. } 2016^{60}\end{array}$ & CAF & $\mathrm{CAF}+\mathrm{CTG}$ & $\begin{array}{l}0.2 \% \text { CHX } \\
\text { NSAIDs } \\
\text { Antibiotic } \\
\text { for } 7 \text { days } \\
\text { Sutures } \\
\text { removal at } \\
15 \text { days }\end{array}$ & 18 & $\begin{array}{c}\text { Control: } \\
84.6 \pm 19 \text {. } \\
6 \\
\text { Test: } \\
81.7 \pm 17 \text {. } \\
8\end{array}$ & $\begin{array}{l}\text { Both } \\
\text { techniques } \\
\text { were } \\
\text { effective in } \\
\text { reducing } \\
\text { GRs }\end{array}$ \\
\hline $\begin{array}{l}\text { Berlucchi et al. } \\
2002^{53}\end{array}$ & $C A F+E M D$ & $\begin{array}{l}C A F+C T G \\
+E M D\end{array}$ & $\begin{array}{l}0.12 \% \text { CHX } \\
\text { NSAIDs } \\
\text { Sutures } \\
\text { removal at } \\
14 \text { days }\end{array}$ & 6 & $\begin{array}{l}\text { Control: } \\
93.97 \\
\text { Test: } \\
93.59\end{array}$ & $\begin{array}{l}\text { Both } \\
\text { techniques } \\
\text { were highly } \\
\text { effective in } \\
\quad \text { the } \\
\text { treatment } \\
\text { of GRs }\end{array}$ \\
\hline $\begin{array}{cc}\text { Chevalier et al. } \\
2017^{61} & \begin{array}{c}\text { Two sessions } \\
\text { of } \\
\text { professional } \\
\text { cleaning and } \\
\text { OHI }\end{array} \\
\end{array}$ & $\mathrm{CAF}+\mathrm{CTG}$ & $\mathrm{CAF}+\mathrm{XCM}$ & $\begin{array}{l}0.2 \% \mathrm{CHX} \\
\text { NSAIDs } \\
\text { Sutures } \\
\text { removal } \\
\text { NR }\end{array}$ & 12 & $\begin{array}{l}\text { Control: } \\
94.44 \\
\text { Test: } \\
87.50\end{array}$ & $\begin{array}{l}\text { No } \\
\text { significant } \\
\text { differences } \\
\text { between } \\
\text { the two } \\
\text { groups }\end{array}$ \\
\hline $\begin{array}{l}\text { OHI and root } \\
\text { planing of the } \\
\text { GR }\end{array}$ & CAF & $C A F+E M D$ & $\begin{array}{l}0.12 \% \text { CHX } \\
\text { NSAIDs } \\
\text { Antibiotic } \\
\text { for } 3 \text { days } \\
\text { Sutures } \\
\text { removal at } \\
14 \text { days }\end{array}$ & 24 & $\begin{array}{l}\text { Control: } \\
86.67 \\
\text { Test: } \\
90.67\end{array}$ & $\begin{array}{l}\text { Root } \\
\text { coverage } \\
\text { outcomes } \\
\text { was similar } \\
\text { in both } \\
\text { groups }\end{array}$ \\
\hline $\begin{array}{cc}\text { Francetti et al. 2004 } & \mathrm{OHI} \text { and SRP } \\
62 & \text { (if indicated) }\end{array}$ & $C A F+F R P A$ & I & $\begin{array}{l}0.12 \% \mathrm{CHX} \\
\text { Sutures }\end{array}$ & 12 & 96.15 & $\begin{array}{l}\text { Excellent } \\
\text { gain in root }\end{array}$ \\
\hline
\end{tabular}

This article is protected by copyright. All rights reserved. 


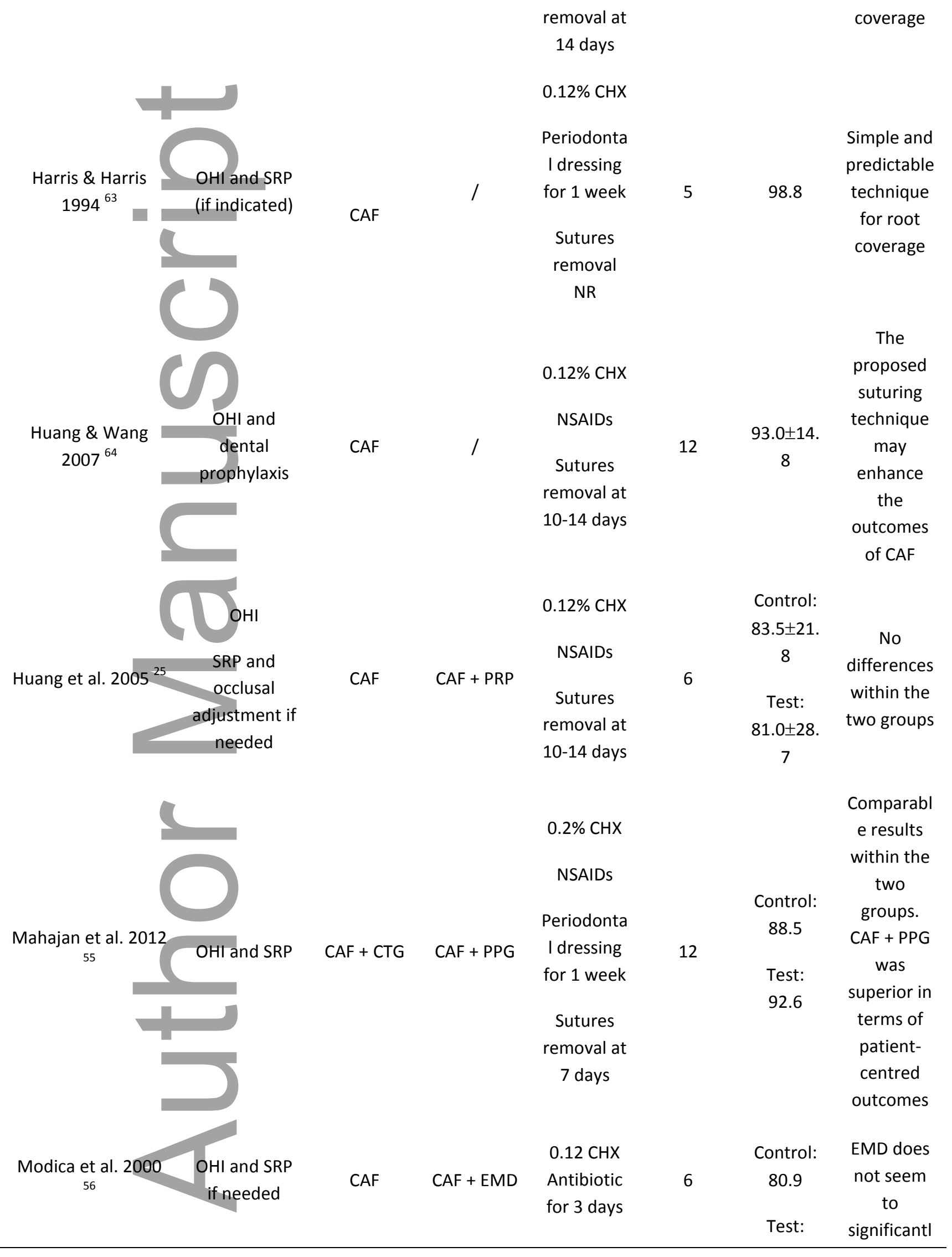

This article is protected by copyright. All rights reserved. 


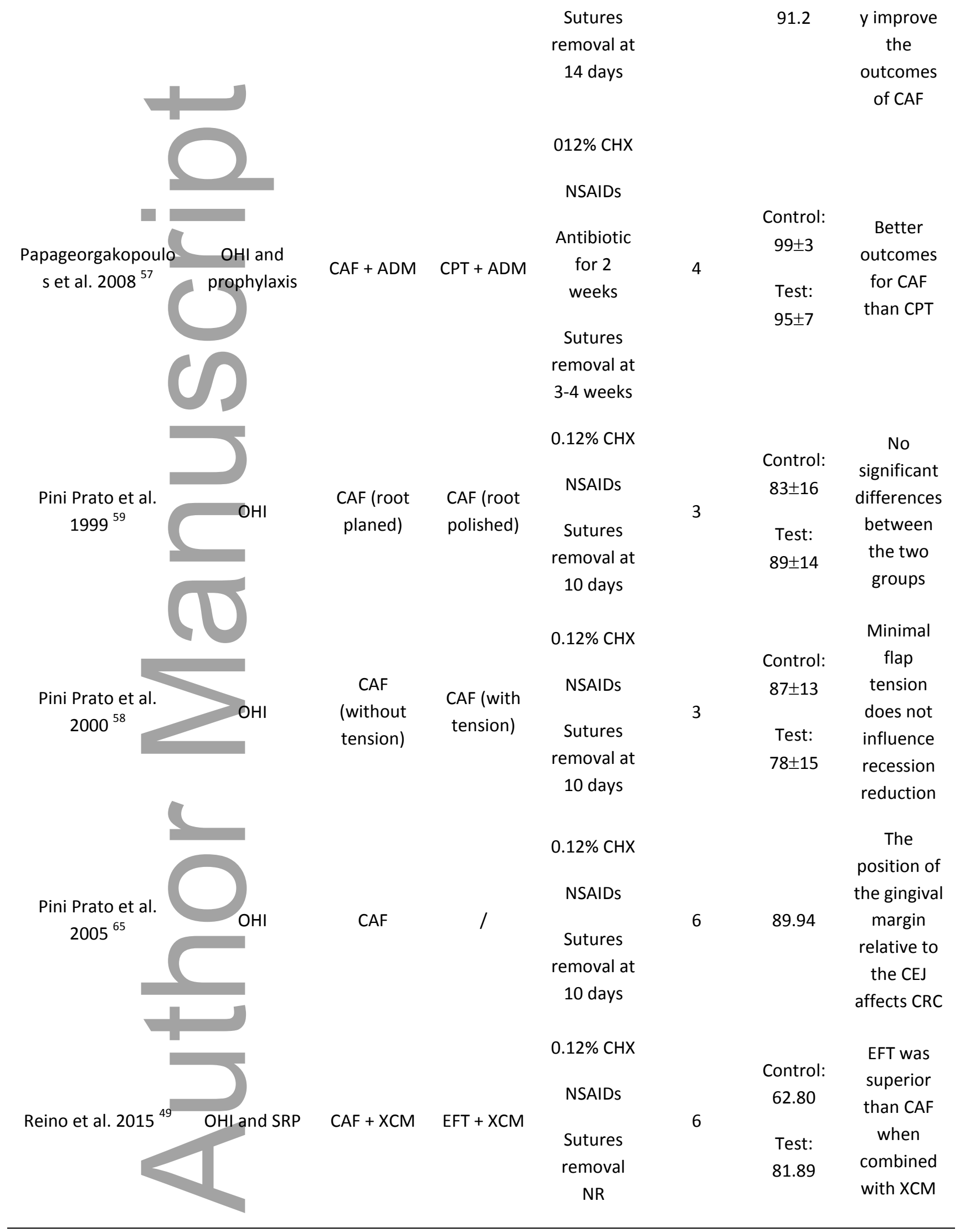

This article is protected by copyright. All rights reserved. 
$\mathrm{OHI}$, scaling
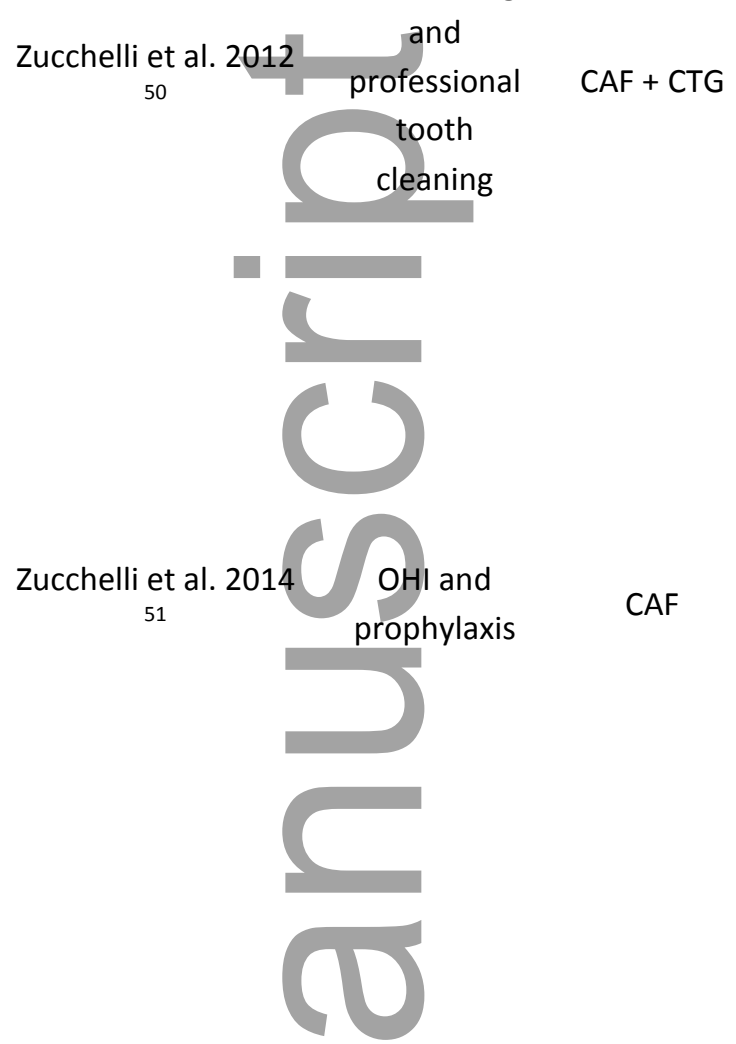

Zuhr et al. $2014^{52} \quad$ OHI and prophylaxis
$0.12 \% \mathrm{CHX}$

NSAIDs

LMCAF

Sutures

removal at

14 days

$0.12 \% \mathrm{CHX}$

NSAIDs

CAF

$C A F+L S T$

Sutures

removal at

14 days

$\mathrm{CHX}$

NSAIDs

$C A F+E M D \quad T U N+C T G$

Sutures

removal at

7 days
Both

Control: techniques

$88.8 \pm 11$. were

12

2 successful

in

Test: treatment

74.2 $\pm 8.2 \quad$ GRs at

molar sites

$\mathrm{CAF}+\mathrm{LST}$

removal

was more

effective

Control: than CAF

97.87

alone in

the

Test:

82.8

treatment of GRs affecting lower incisors

Control: TUN 71.8 \pm 20 . showed 3 better clinical

Test: outcomes $98.4 \pm 3.6$ than $\mathrm{CAF}$

Note. NR: Not Reported. OHI: Oral hygiene instruction. SRP: Scaling and root planing. CPT: Coronally positioned tunnel. EFT: Extended flap technique. LMCAF: Laterally moved, coronally advanced flap. LST: Labial submucosal tissue. TUN: tunnel technique. CHX: Chlorhexidine. NSAID: Non-Steroidal Anti-Inflammatory Drugs.

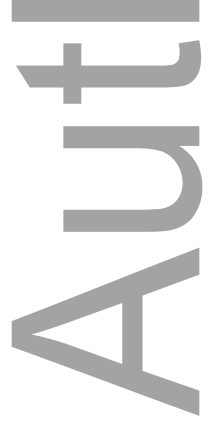

This article is protected by copyright. All rights reserved. 
Table 3. Frequency of treated teeth according to their location

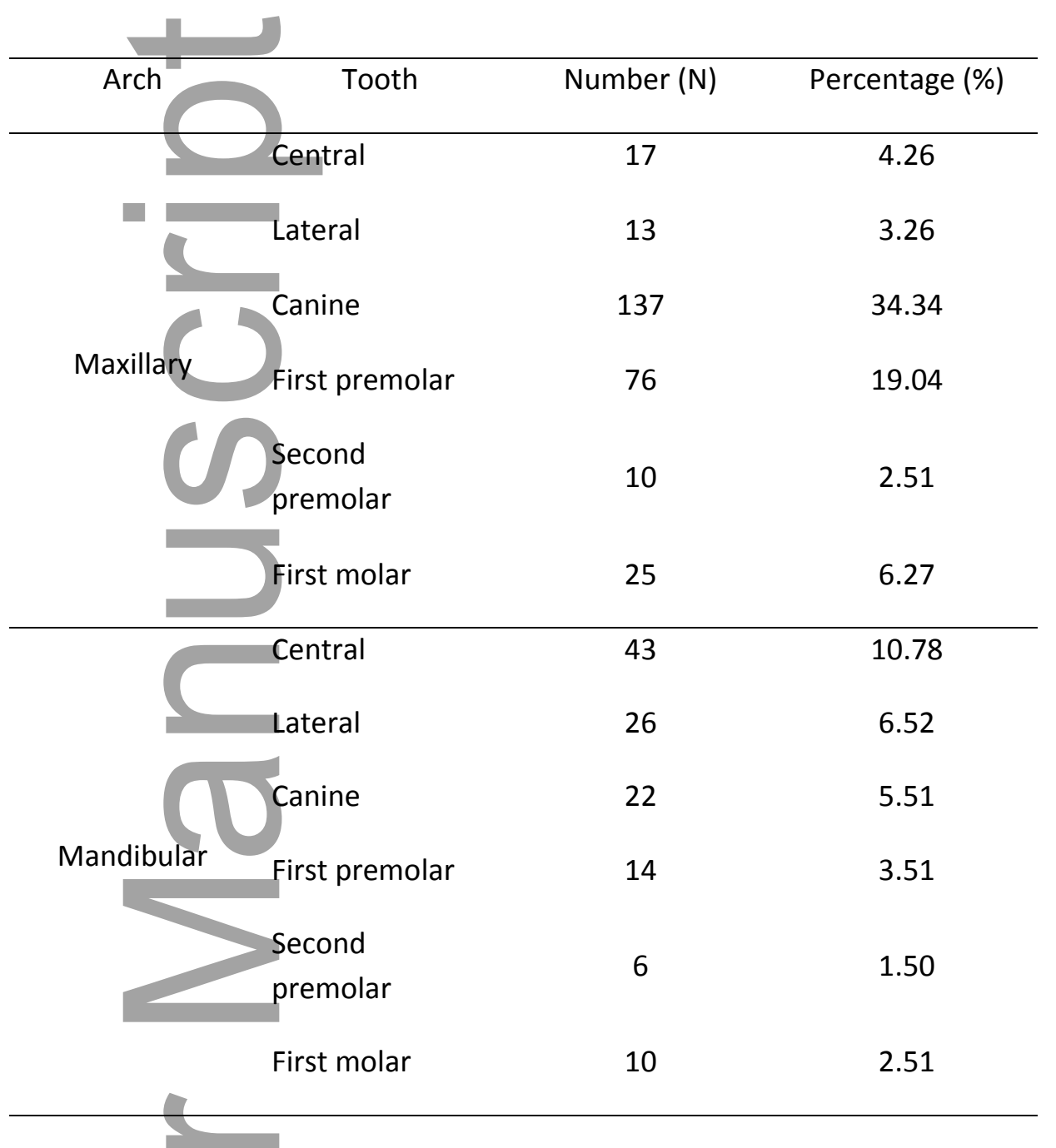

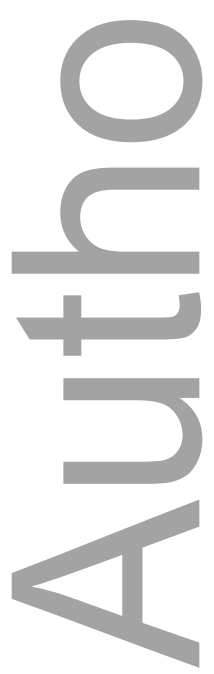

This is the author manuscript accepted for publication and has undergone full peer review but has not been through the copyediting, typesetting, pagination and proofreading process, which may lead to differences between this version and the Version of Record. Please cite this article as doi: 10.1002/JPER.18-0201.

This article is protected by copyright. All rights reserved. 
Table 4. Comparison of mean Root Coverage (mRC), Complete Root Coverage (CRC), Keratinized Tissue Gain (KT gain), Probing Depth reduction (PD red) and Clinical Attachment Level gain (CAL gain) based on tooth location

\begin{tabular}{cccccccc}
\hline Comparison & $\mathrm{mRC}$ & $\mathrm{CRC}$ & $\begin{array}{c}\text { Odds ratio } \\
\text { CRC }\end{array}$ & KT gain & PD red & CAL gain \\
& & & & & & \\
\hline Anterior / Posterior teeth & $\mathrm{p}=0.02^{*}$ & $\mathrm{p}=0.01^{*}$ & $1.63^{*}$ & $\mathrm{p}=0.04^{*}$ & $\mathrm{p}<0.01^{*}$ & $\mathrm{p}=0.002^{*}$ \\
Maxillary - Mandibular teeth & $\mathrm{p}=0.45$ & $\mathrm{p}=0.95$ & 1.27 & $\mathrm{p}<0.001^{\dagger}$ & $\mathrm{p}<0.001^{\dagger}$ & $\mathrm{p}<0.001^{\dagger}$ \\
Right - Left teeth & $\mathrm{p}=0.12$ & $\mathrm{p}=0.38 \ddagger$ & $1.60 \ddagger$ & $\mathrm{p}=0.74$ & $\mathrm{p}=0.86$ & $\mathrm{p}=0.76$ \\
\hline
\end{tabular}

Note. ${ }^{*}$ statistically significant $p$-value favoring anterior teeth compared to posterior teeth; ${ }^{\dagger}$ statistically significant $p$-value favoring mandibular teeth compared to maxillary teeth; ‡ statistically significant $p$-value favoring right teeth compared to maxillary teeth

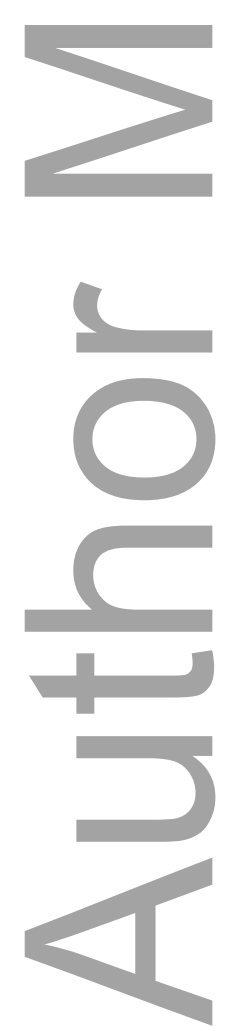

This is the author manuscript accepted for publication and has undergone full peer review but has not been through the copyediting, typesetting, pagination and proofreading process, which may lead to differences between this version and the Version of Record. Please cite this article as doi:

10.1002/JPER.18-0201.

This article is protected by copyright. All rights reserved. 